\title{
A reconstruction of Iberia accounting for Western Tethys-North Atlantic kinematics since the late-Permian-Triassic
}

\author{
Paul Angrand $^{1}$, Frédéric Mouthereau ${ }^{1}$, Emmanuel Masini $^{2,3}$, and Riccardo Asti ${ }^{4}$ \\ ${ }^{1}$ Geosciences Environnement Toulouse (GET), Université de Toulouse, UPS, Univ. Paul Sabatier, CNRS, \\ IRD, 14 av. Edouard Belin, 31400 Toulouse, France \\ ${ }^{2} \mathrm{M} \& U$ sas, 38120 Saint-Égrève, France \\ ${ }^{3}$ ISTerre, Université Grenoble Alpes, 38000 Grenoble, France \\ ${ }^{4}$ Université de Rennes, CNRS, Géosciences Rennes-UMR 6118, 35000 Rennes, France
}

Correspondence: Paul Angrand (paul.angrand.geology@gmail.com)

Received: 20 February 2020 - Discussion started: 6 March 2020

Revised: 12 May 2020 - Accepted: 27 May 2020 - Published: 21 July 2020

\begin{abstract}
The western European kinematic evolution results from the opening of the western Neotethys and the Atlantic oceans since the late Paleozoic and the Mesozoic. Geological evidence shows that the Iberian domain recorded the propagation of these two oceanic systems well and is therefore a key to significantly advancing our understanding of the regional plate reconstructions. The late-Permian-Triassic Iberian rift basins have accommodated extension, but this tectonic stage is often neglected in most plate kinematic models, leading to the overestimation of the movements between Iberia and Europe during the subsequent Mesozoic (Early Cretaceous) rift phase. By compiling existing seismic profiles and geological constraints along the North Atlantic margins, including well data over Iberia, as well as recently published kinematic and paleogeographic reconstructions, we propose a coherent kinematic model of Iberia that accounts for both the Neotethyan and Atlantic evolutions. Our model shows that the Europe-Iberia plate boundary was a domain of distributed and oblique extension made of two rift systems in the Pyrenees and in the Iberian intra-continental basins. It differs from standard models that consider leftlateral strike-slip movement localized only in the northern Pyrenees in introducing a significant strike-slip movement south of the Ebro block. At a larger scale it emphasizes the role played by the late-Permian-Triassic rift and magmatism, as well as strike-slip faulting in the evolution of the western Neotethys Ocean and their control on the development of the Atlantic rift.
\end{abstract}

\section{Introduction}

Global plate tectonic reconstructions are mostly based on the knowledge and reliability of magnetic anomalies that record age, rate, and direction of sea-floor spreading (Stampfli and Borel, 2002; Müller et al., 2008; Seton et al., 2012). Where these constraints are lacking or their recognition is ambiguous, kinematic reconstructions rely on the description and interpretation of the structural, sedimentary, igneous and metamorphic rocks of rifted margins and orogens (e.g., Handy et al., 2010; McQuarrie and Van Hinsbergen, 2013). However, the required quantification and distribution of finite strain into deformed continents often remain uncertain due to the poor preservation of pre-kinematic markers.

A well-known example of this problem is illustrated by the contrasting Mesozoic plate kinematic models proposed for the Iberian plate relative to Europe with significant implications for the reconstructions of the Alpine Tethys and Atlantic oceans (Olivet, 1996; Handy et al., 2010; Sibuet et al., 2004; Vissers and Meijer, 2012; Barnett-Moore et al., 2016; Nirrengarten et al., 2018). This movement is proposed to be imposed by the northward propagation of the North Atlantic rifting during the Triassic-Early Cretaceous period (Olivet, 1996; Stampfli et al., 2001; Handy et al., 2010; BarnettMoore et al., 2016; Nirrengarten et al., 2018). Although all of the proposed reconstructions agree on the amplitude and kinematics of a 400-500 km left-lateral strike-slip motion between Europe and Iberia after the Variscan orogeny, its precise timing and spatial partitioning is debated and remains unresolved so far (e.g., Vissers and Meijer, 2012; Barnett- 
Moore et al., 2016). Because of the lack of geological constraints, such a large strike-slip displacement has been supposedly exported along the North Pyrenean Fault (Fig. 1a) (e.g., Choukroune and Mattauer, 1978; Debroas, 1987, 1990; Lagabrielle et al., 2010; Jammes et al., 2009). Here again, previous studies were not conclusive so there are currently no firm geological constraints nor geophysical evidence across the Pyrenees to argue for significant transcurrent deformation during the Jurassic or the Cretaceous (Olivet, 1996; Masini et al., 2014; Canérot, 2016; Chevrot et al., 2018). Other studies have suggested that this conclusion might hold true back to the Permian, based on local geological evidence from the western Pyrenees (Saspiturry et al., 2019).

An alternative scenario has recently emerged (Tugend et al., 2015; Nirrengarten et al., 2018; Tavani et al., 2018), proposing a spatiotemporal partitioning of the deformation in a wider deformation corridor than the single Pyrenean belt. It suggests that the transcurrent deformation that results from the eastwards movement of Iberia occurred mainly during the Late Jurassic-Early Cretaceous in northern Iberia along a $100 \mathrm{~km}$ scale pull-part or en échelon rift basins formed by the NW-SE-trending Iberian massifs. Indeed, along these massifs, several extensional basins recorded major subsidence and strike-slip deformation during the latePermian to middle-Cretaceous time interval (Alvaro et al., 1979; Salas et al., 2001; Aldega et al., 2019; Aurell et al., 2019; Soto et al., 2019). However, no geological evidence for lithosphere-scale strike-slip movements has yet been clearly defined in the intra-Iberian basins.

These basins separate the Ebro continental block from the greater Iberia to the south. The Ebro block is delimited to the north by the Pyrenean system. Extension then migrated and localized to the north (Rat et al., 2019) leading to oceanic spreading in the Bay of Biscay and hyper-extension in the Pyrenean rift basins (Jammes et al., 2009; Lagabrielle et al., 2010; Mouthereau et al., 2014; Tugend et al., 2014, 2015).

Moreover, the contribution of pre-Late Jurassic-Early Cretaceous extension phases might have been substantial to the overall crustal attenuation and movements of Iberia (Fig. 1a) (Fernández, 2019; Soto et al., 2019). Indeed, two major geodynamic events, the late-Permian-Early Triassic breakup of Pangea and the opening of the Neotethys and the Late Triassic-Early Jurassic central Atlantic magmatic event preceding the opening of the North Atlantic Ocean are recorded in Iberia and contributed to the finite crustal thinning. Therefore, all full-fit reconstructions considering that extension between Iberia and Newfoundland only initiated by Jurassic times in the North Atlantic realm invariably overestimate the amount of strike-slip motion required in the Pyrenees and northern Iberia from the Jurassic onward (Barnett-Moore et al., 2016; Nirrengarten et al., 2018).

Here, we examine the possible contribution of the latePermian-Triassic extension to the plate reconstruction of Iberia between the Neotethys and the North-central Atlantic domains and its impact on the definition of the spatial and temporal distribution of strike-slip movement between Iberia and Europe. By integrating constraints from 270 to $100 \mathrm{Ma}$, our reconstructions bring to light the connection between the Tethyan and the Atlantic oceanic domains.

\section{Late-Permian-Triassic rifting and magmatism in the North Atlantic and western Europe}

The tectonic and thermal evolution of the "Iberian buffer" between Africa and Europe at the Permian-Triassic boundary reflects the complex post-Variscan evolution of the Iberian lithosphere. This domain has in fact experienced significant Permian crustal thinning in relation to the post-orogenic collapse of the Variscan belt (De Saint Blanquat et al., 1990; de Saint Blanquat, 1993; Vissers, 1992; Saspiturry et al., 2019) and the fragmentation of the Gondwana margin more broadly (Schettino and Turco, 2011; Stampfli and Borel, 2002; Ziegler, 1989, 1990). This upper-Permian-Lower Triassic phase is associated with the deposition of thick detrital non-marine deposits in intra-continental basins. Sedimentation became carbonaceous during the Middle Triassic. Finally, the Late Triassic is characterized by a thick evaporitic (mainly salt) sequence (e.g., Ortí et al., 2017). However, this phase also resulted in lithospheric mantle delamination and thinning (Malavieille et al., 1990; Fabriès et al., 1991, 1998; Ziegler et al., 2004; Ziegler and Dèzes, 2006; Denèle et al., 2014).

Crustal thinning, attested by thick late-Permian-Triassic detrital rift basins deposited above an erosive surface, is well documented on seismic lines along the Atlantic margins (Fig. 2): the Nova Scotia-Moroccan basins (Welsink et al., 1989; Deptuck and Kendell, 2017; Hafid, 2000); IberiaGrand Banks (Balkwill and Legall, 1989; Leleu et al., 2016; Spooner et al., 2019); the southern North Atlantic (Tankard and Welsink, 1987; Doré, 1991; Doré et al., 1999; Štolfová and Shannon, 2009; Peace et al., 2019b; Sandoval et al., 2019); the northern Western Approaches (Avedik, 1975; Evans, 1990; McKie, 2017); and the North Sea (McKie, 2017; Jackson et al., 2019; Hassaan et al., 2020; Phillips et al., 2019). Onshore Iberia (Arche and López Gómez, 1996; Soto et al., 2019) and in the Pyrenean-Provence domains (Lucas, 1985; Espurt et al., 2019; Cámara and Flinch, 2017; Bestani et al., 2016) (Fig. 1b), an angular unconformity is observed between the Paleozoic and the Permian-Triassic strata (Fig. 2).

The Permian tectonic phase is contemporaneous with widespread magmatism related to the breakup of Pangea, and its transition toward diffuse extension. This is observed in present-day rifted margins of the North Atlantic such as the North Sea and Norwegian-Danish basins (Glennie et al., 2003), the Western Approaches (McKie, 2017), the Scottish Midland Valley (Upton et al., 2004), and the basement of Cenozoic collision belts around Iberia, for instance, in the Pyrenees (Lago et al., 2004a; Denèle et al., 2012; Vacherat 

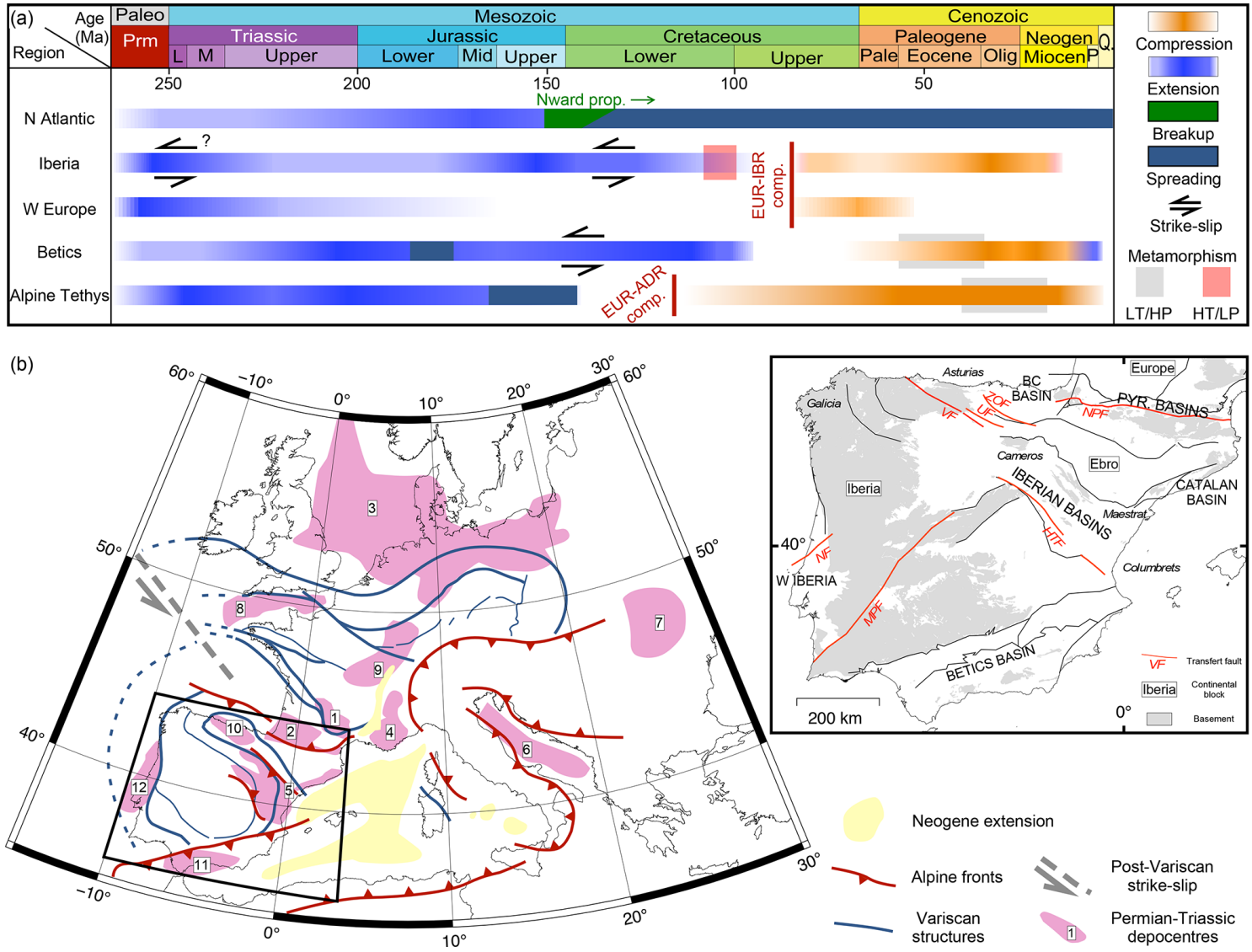

Figure 1. Geodynamic chart and localization of the study area. (a) Geodynamic chart of the main structural areas of the Iberian domain. (b) Location map of western Europe, showing the areas that are deformed in compression and extension and Permian-Triassic depocenters. (1) French Massif Central; (2) Aquitaine Basin and Pyrenees; (3) Germanic Basin; (4) southeastern France; (5) Iberian Basin; (6) Italy; (7) central Europe; (8) English Channel; (9) northeastern France; (10) Basque-Cantabrian Basin; (11) Betics; (12) West Iberia. Inset: Map of Iberia showing the main structures and transforms (red) and sedimentary basins (capitalized and italicized text) and sub-basins (italicized text). BC: Basque-Cantabrian; HTF: High Tagus Fault; MPF: Messejana-Plasencia Fault; NF: Nazaré Fault; NPF: North Pyrenean Fault; PYR: Pyrenean; UF: Ubierna Fault; VF: Ventaniella Fault; ZOF: Zamanza-Oña Fault.

et al., 2017; Saspiturry et al., 2019), the Iberian Range (Lago et al., 2004b), the Catalan Coastal Ranges (Solé et al., 2002), and the Betic Cordillera (Sánchez-Navas et al., 2017).

An expression of the continued lithospheric thinning and thermal instability associated with high heat flow during the Permian (McKenzie et al., 2015) and the Triassic (Peace et al., 2019a, and references therein) is recorded in the central and southern North Atlantic. Lithospheric extension prior to (or associated with the premises of the subsequent) Early Jurassic continental breakup in the central Atlantic then favored the drainage of mantle melt reservoir (Silver et al., 2006; Peace et al., 2019a), attested by the very rapid emergence of the widespread tholeiitic magmatic CAMP (Central Atlantic Magmatic Province) event at the TriassicJurassic boundary (200 Ma) in the central Atlantic (Olsen, 1997; Marzoli et al., 1999; McHone, 2000). The CAMP extends to Iberia as large-scale volcanic intrusions such as the Messejana-Plasencia dyke (Cerbiá et al., 2003) in Iberia and the Late Triassic-Early Jurassic ophitic magmatism in the Pyrenees (e.g., Azambre et al., 1987). Extension and salt movements in the North Sea basins during the Late Triassic further point to the propagation of the North Atlantic rift (Goldsmith et al., 2003).

The persistence of shallow-marine to non-marine deposition during this period contrasts with the large accommodation space that is required at a larger scale to sediment the giant evaporitic province in the late Permian (Jackson et al., 2019) and in the Late Triassic (Štolfová and Shannon, 2009; Leleu et al., 2016; Ortí et al., 2017). Therefore the subsidence appears much lower than that predicted by a simple isostatic model of crustal thinning (McKenzie, 1978).

Two hypotheses may be invoked to explain the difference with the McKenzie model. (1) The first is a reduction in mantle density during lithospheric thinning, due to mantle phase transitions to lighter mineral phases because of crustal attenuation (Simon and Podladchikov, 2008) and/or 

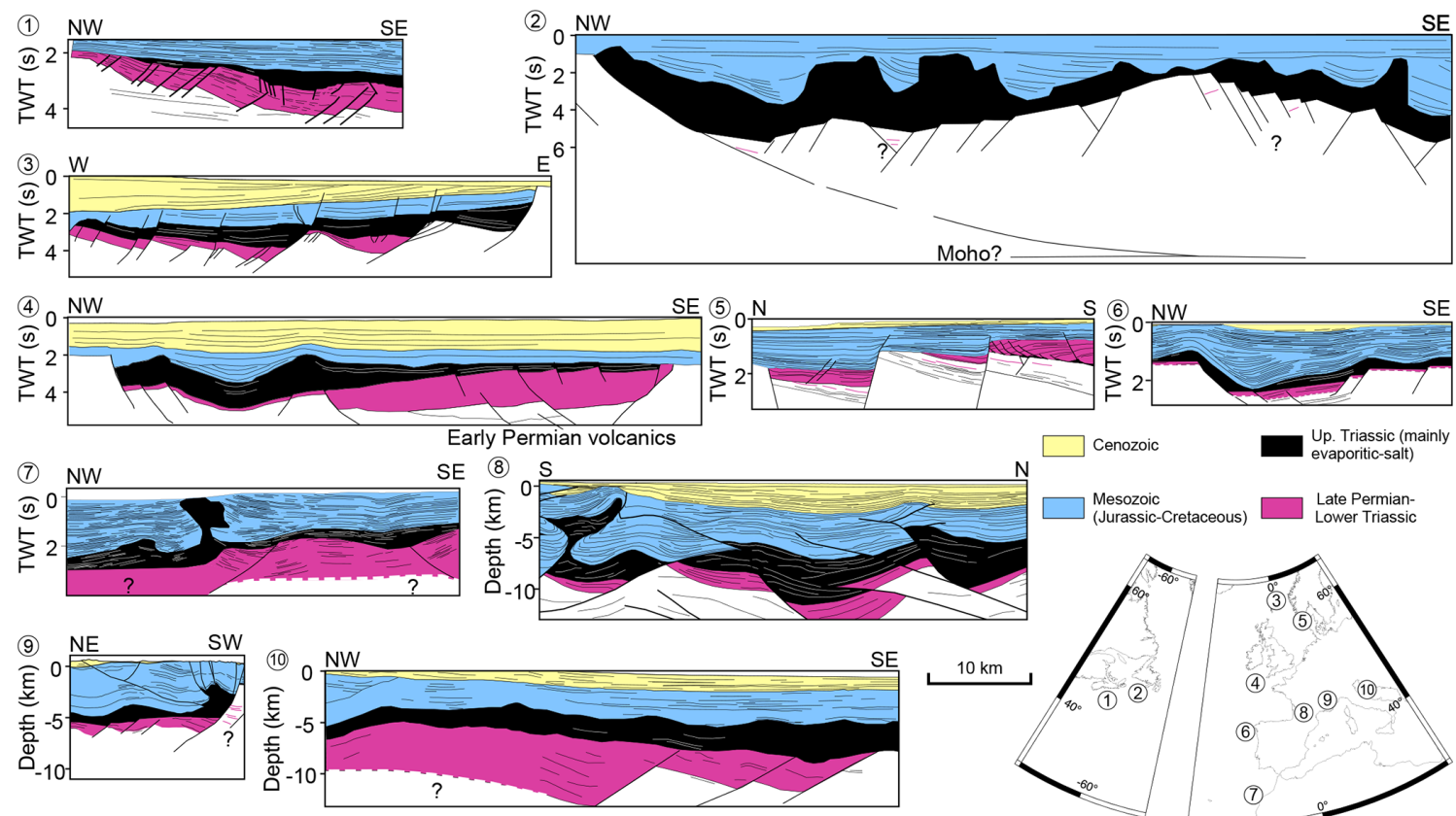
$10 \mathrm{~km}$

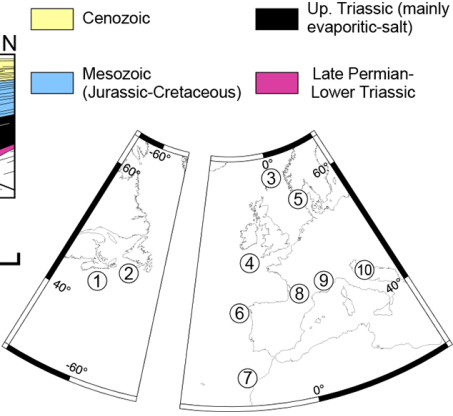

Figure 2. Compilation of interpreted seismic profiles along the North Atlantic margins and in western Europe. (1) Deptuck and Kendell (2017); (2) Balkwill and Legall (1989); (3)-(4) McKie (2017); (5) Philipps et al. (2019); (6) Rasmussen et al. (1998); (7) Hafid (2000); (8) Espurt et al. (2019); (9) Bestani et al. (2016); (10) Scisciani and Esestime (2017).

due to the trapping of melt in the rising asthenosphere before breakup (Quirk and Rüpke, 2018) in addition to magmatic rethickening of attenuated crust by underplating. (2) Another possible hypothesis for the Permian-Triassic topographic evolution of the Iberian basins relies on the complex postVariscan evolution of the Iberian lithosphere. Recent studies have shown that during the existence of the Pangea supercontinent (300 to $200 \mathrm{Ma}$ ), temperature in the asthenospheric mantle increased due to the thermal insulation by the continental lid (Coltice et al., 2009; Ganne et al., 2016). This thermal insulation would be responsible for the accumulation of magmatic material of the CAMP (see Peace et al., 2019a, and references therein). Such a mantle thermal anomaly could have further inhibited lithospheric mantle re-equilibration after late-Variscan mantle delamination over a long time span. This model requires a strong impermeability of the overlying lithosphere (Silver et al., 2006). As a consequence of the Pangea breakup and magmatic emission at the TriassicJurassic boundary, the lithospheric mantle started to cool and thicken, causing isostatic subsidence of the thinned Iberian crust and resulting in topographic drop.

This argues for a protracted period of $\sim 100 \mathrm{Myr}$ (late Carboniferous to Late Triassic) of continental lithosphere thinning and magmatism prior to Early Cretaceous breakup of the North Atlantic but contemporaneous with the Tethyan evolution. One main consequence is that the late-PermianTriassic extension has been so far underestimated in plate reconstructions, despite evidence for continuous extension.

\section{From late-Permian-Early Triassic rifting to Late Jurassic-Early Cretaceous rifting in Iberia}

The Permian-Triassic basins of Iberia are exposed in the inverted Mesozoic rift basins of the Basque-Cantabrian and Pyrenean belts, the Iberian Ranges, the Catalan Range and the Betic Cordillera (Alvaro et al., 1979; Lagabrielle et al., 2020) (Figs. 1b and 3a). The coincidence between the orientations of the Alpine orogenic segments and the spatial distribution of Permian-Triassic depocenters (Figs. 1b and 3a) suggests that the Cenozoic orogenic cycle largely inherits the earliest stages of the Tethyan rift evolution. In addition, these Permian-Triassic depocenters are superposed over Variscan structures (Fig. 1b), suggesting antecedent tectonic control of the Tethyan continental rift segment by the late-Variscan evolution.

We analyze subsidence reconstructed based on a compilation of well data and a synthetic stratigraphic section in the Aquitaine Basin (Brunet, 1984), the Cameros and Iberian basins (Salas and Casas, 1993; Salas et al., 2001; OmodeoSalé et al., 2017), western Iberia (Spooner et al., 2019), and the Betics (Hanne et al., 2003) to estimate 1D mean tectonic subsidence evolution in these areas (Fig. 3b; see Supplement for individual tectonic subsidence curves in each region). For each region, we calculated the mean tectonic subsidence, following the approach of Spooner et al. (2019) for which wells that do not sample the entire stratigraphy are corrected based on the oldest well of the region. We then calculated the mean 

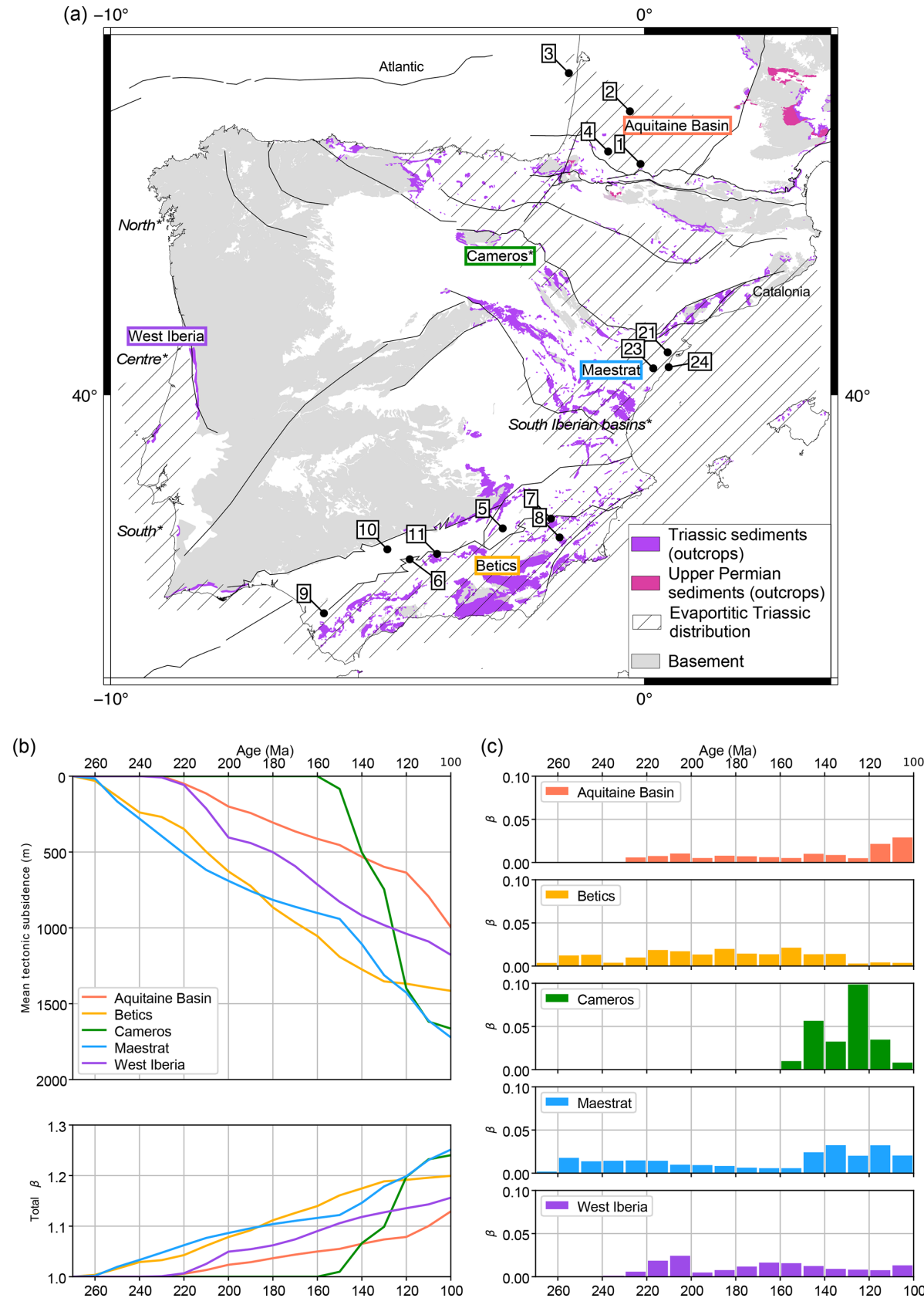

Figure 3. Late Permian-Triassic deposits and subsidence analyses. (a) Map of the upper-Permian-Triassic sediment outcrops, main depocenters, and distribution of the Upper Triassic evaporitic sequence in Iberia and southwest France. (b) Top: mean tectonic subsidence curves in the Aquitaine Basin (Brunet, 1984), Betics (Hanne et al., 2003), Cameros Basin (Salas and Casas, 1993; Salas et al., 2001; Omodeo-Sale et al., 2017), Maestrat Basin (Salas and Casas, 1993; Salas et al., 2001), and West Iberia (Spooner et al., 2018). See Supplement for individual tectonic subsidence curves in each region. (1) Ger1; (2) Lacquy1; (3) Sextant1; (4): Lacq301; (5) Santiago de la Espada; (6) Nueva Carteya1; (7) Rio Segura G1; (8) Espugna; (9) Betica 18-1; (10) Rio Guadalquivir; (11) Fusanta; (12) Lazaro; (13) Fuentatoba*; (14) Poveda*; (15) Cameros2*; (16) Enciso*; (17) Rollamentia*; (18) Castellijo*; (19) Molino*; (20) Yanguas*; (21) Mirambell; (22) Amposta Marino C3; (23) Salzedella; (24): Maestrazgo; (25): South Iberian Basin; (26): West Iberia south; (27): West Iberia central; (28): West Iberia north. Synthetic wells (shown by ${ }^{*}$ ) are not represented on the map. Bottom: total stretching factor $(\beta)$ (isostatic calculation, Watts, 2001) calculated from the mean tectonic subsidence of each region. (c) Incremental stretching factor $(\beta)$ with a 10 Myr time step. 
crustal stretching ( $\beta$ factor, Fig. 3c) for each tectonic subsidence curve based on isostatic calculation (Watts, 2001).

During the late-Permian-Early Triassic, a first phase of significant tectonic subsidence, up to $500 \mathrm{~m}$, is recorded in the Maestrat Basin and on the Iberia paleomargin of the Betic basins (Salas and Casas, 1993; Van Wees et al., 1998; Salas et al., 2001; Hanne et al., 2003; Soto et al., 2019) (Fig. 3bc). This phase is contemporaneous with the westward migration of marine deposition in the Iberian basins during the Middle Triassic (Anisian-Carnian, 240-230 Ma). Sopeña et al. (1988) argue that Tethyan rifting propagated westward into the Iberian continental interior. The same evolution is suggested by the stratigraphy and the depositional evolution constraints from the Catalan and Basque-Cantabrian basins (Sopeña et al., 1988), and in the Aquitaine domain (Fig. 3b), although it is ill-defined for Permian times.

During the Late Triassic (220-200 Ma), the regional tectonic subsidence in all regions is found to be associated with the deposition of evaporites that spread all over Iberia, in the Betics, western Iberia, and in the Aquitaine Basin (Fig. 3a). The distribution of salt terranes in Iberia and its surroundings (Fig. 3a) highlights a very large subsiding domain for this period. A maximum mean subsidence of $700 \mathrm{~m}$ is inferred in the Maestrat Basin for Triassic times. The relatively rapid subsidence in the Triassic contrasts with the slower subsidence observed during the Early-Middle Jurassic. A notable exception is depicted by the slight increase in subsidence between 200 and $150 \mathrm{Ma}$ in the Betics (Fig. 3b-c), consistent with rifting across the Iberia-Africa boundary (Ramos et al., 2016; Fernández, 2019).

A third Late Jurassic-Early Cretaceous phase (150$110 \mathrm{Ma}$ ) is marked by the increase in tectonic subsidence in the Iberian basins, coeval with the expected timing of strikeslip deformation and rifting in the Cameros (e.g., Rat et al., 2019; Aurell et al., 2019) and Columbrets (Etheve et al., 2018) basins as well as the initiation of mantle exhumation in the Atlantic domain (Fig. 1a) (Murillas et al., 1990; Mohn et al., 2015). The most recent extension is recorded in the Aquitaine Basin at 120-100 Ma, which reflects the onset of oceanic spreading in the Bay of Biscay (Fig. 3b-c).

Subsidence analyses show thinning events in Iberia that reveal control by Tethys and Atlantic rifting (late PermianLate Triassic) and later by the intra-Iberian-Pyrenean rift events (Late Jurassic-Early Cretaceous). In the Iberian Basin, this latter event is characterized by a relatively large and short-lived subsidence $(1.5 \mathrm{~km}$ in $30 \mathrm{Myr})$ localized in narrow basins that suggests the strike-slip nature of the boundary between Ebro and Iberia in the Late Jurassic. The long-lasting rift evolution, however, shows an average low stretching factor of about 1.2.

\section{Methodology}

\subsection{Previous kinematic models}

We compile and implement previous kinematic models involving Iberia (Fig. 4). The objective is to establish a coherent kinematic model of Iberia that considers both the evolution of the Neotethyan and Atlantic regions. Global kinematic models (e.g., Müller et al., 2019) are based on the assimilation of geological and geophysical information at a large scale to allow a dynamic understanding of Earth's plate tectonics but do not aim to solve regional tectonic issues such as strain partitioning between Iberia and Europe. In contrast, regional models are focused on the reconstruction of the North Atlantic (e.g., Barnett-Moore et al., 2016; Nirrengarten et al., 2018; Peace et al., 2019b) or are interested in the reconstruction of the Alpine orogen with inferences on the kinematics of the Tethys and Adria (Schmid et al., 2008; Handy et al., 2010; Van Hinsbergen et al., 2020).

North Atlantic reconstructions use offshore geophysical constraints from the northwest Iberian margins and pay relatively little attention to the geological evolution of the Pyrenees and other orogenic domains in Iberia (e.g., Sibuet et al., 2004; Barnett-Moore et al., 2016; Nirrengarten et al., 2018). However, these models give fundamental insights into the geometry of the North Atlantic full-fit reconstruction and the timing of oceanic spreading. The nature of some magnetic anomalies in the southern North Atlantic has been the matter of considerable debate (Olivet, 1996; Sibuet et al., 2004; Vissers and Meijer, 2012; Barnett-Moore et al., 2016). Here, we adopt the reconstruction of Nirrengarten et al. (2018), who propose a model based on the re-evaluation of magnetic anomalies that are considered not oceanic before C34 (83 Ma) and therefore not suitable for kinematic studies (Nirrengarten et al., 2017).

Reconstructions of the Alpine domain (Schmid et al., 2008; Handy et al., 2010) and at a larger scale of the Tethys domain (Van Hinsbergen et al., 2020) are keys to understanding the evolution of past oceanic domains now inverted in Alpine orogenic systems (e.g., Paleotethys, Neotethys, Meliata, Pindos, and Vardar oceans). These models however do not account for the recent reconstruction of the southern North Atlantic presented above that have an impact on the movement of Iberia of interest for our study.

\subsection{Reconstruction workflow}

A plate reconstruction from the late Permian to middle Cretaceous is presented in Figs. 5 and 6, based on kinematic modeling using GPlates version 2.1 (Müller et al., 2018). The rotation poles of the main plates are summarized in Table 1 (see also the Supplement for GPlates files).

Our compilation is as follows: (1) the reconstruction of the western Tethys prior to the Late Jurassic is constrained by the kinematic evolution of the Mediterranean region since 


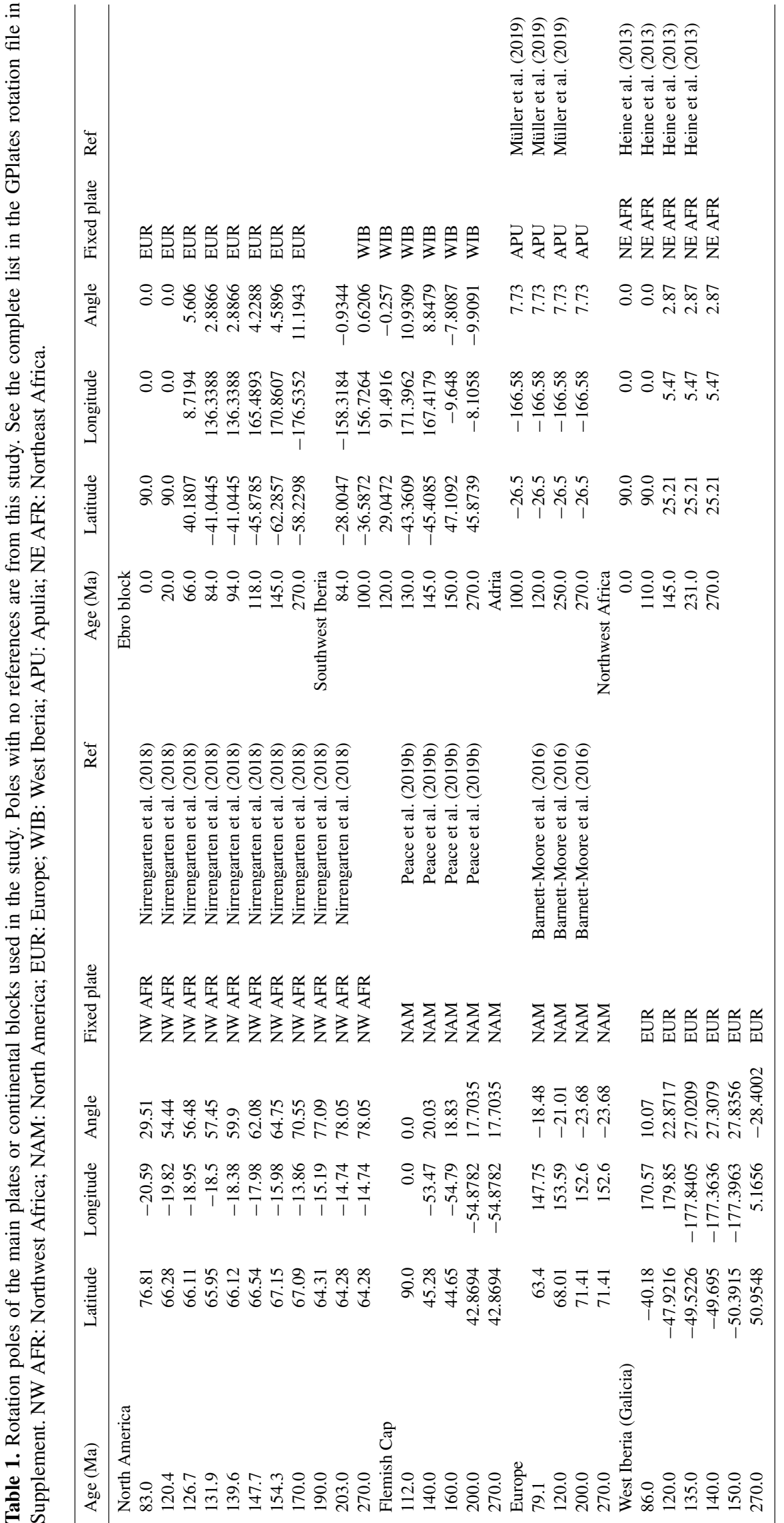



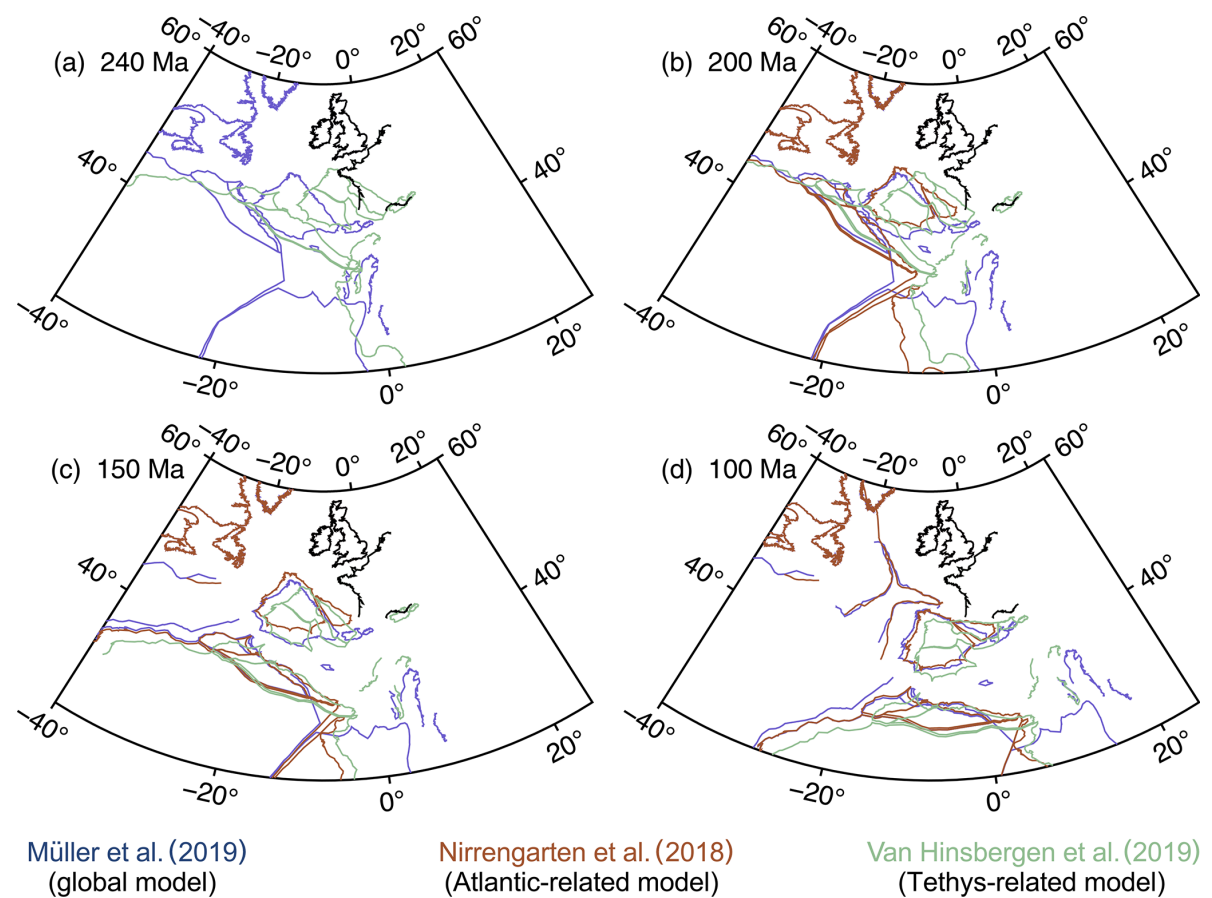

Müller et al. (2019)

Nirrengarten et al. (2018)

(global model)

(Atlantic-related model)

(Tethys-related model)

Figure 4. Compilation of previous global (Müller et al., 2018), Atlantic-related (Nirrengarten et al., 2018), or Tethys-related (Van Hinsbergen et al., 2020) kinematics reconstructions used in our reconstruction, at $240 \mathrm{Ma}$ (a), $200 \mathrm{Ma}$ (b), $150 \mathrm{Ma}$ (c), and $100 \mathrm{Ma}$ (d). Note that the Nirrengarten et al. (2018) reconstruction is not shown at $240 \mathrm{Ma}$ as it is not represented in the original publication.

the Triassic from Van Hinsbergen et al. (2020), which we corrected for overlap of Iberia over western France; (2) the kinematics of Africa follows Müller et al. (2019), based on Heine et al. (2013); (3) for the Late Jurassic and Cretaceous times, we compiled rotation poles of the North AmericaEurope system from Barnett-Moore et al. (2016), updated from Peace et al. (2019b) for North Atlantic continental blocks (Flemish Cap, Orphan Knoll, and Porcupine Bank); (4) our reconstruction of Adria follows the model from Müller et al. (2019), which was modified to account for the possible younger opening of the Ionian Basin (Tugend et al., 2019).

Because there is no motion during the $270-250 \mathrm{Ma}$ interval for the North America and Africa plates relative to Europe (Domeier and Torsvik, 2014), we extended the full-fit of these models to $270 \mathrm{Ma}$.

These input models were then updated according to the following constraints (Table 2): (1) age of rifting, mantle exhumation, onset of oceanic spreading in the Atlantic; (2) the present-day position of ophiolite bodies and the timing of rifting, oceanic spreading and subduction for the Tethyanrelated oceanic domains (Paleotethys, Neotethys, Pindos, Meliata, Vardar); (3) at $100 \mathrm{Ma}$, Iberia is close to the presentday position relative to Europe, so that the late-MesozoicCenozoic Pyrenean shortening is essentially orthogonal.

\subsection{Implementations of the pre-existing models}

A critical step in determining the pre-rifting configuration is the restoration of rifted margins. Here, we adopted the reconstructed continental crust geometry of Nirrengarten et al. (2018). Polygons from the model of Nirrengarten et al. (2018) that are based on Seton et al. (2012) were re-defined such that they include new smaller polygons (continental micro-blocks) separated by deformed areas in Iberia and Adria to account for internal deformation (Fig. 1b).

The kinematics of these continental blocks (e.g., the Ebro block) has been reconstructed using geological constraints inferred from the tectono-sedimentary evolution of intra- and peri-Iberian basins (see Sect. 3 and Fig. 3), which allows defining periods of deformation and subsidence related to extension or transcurrent deformation.

Because a full-fit reconstruction in southwest Iberia leads to significant overlapping between the Flemish Cap and Galicia, we use the Nazaré Fault (Pereira et al., 2017) to segment western Iberia. This allows us to minimize the overlap of northwest Iberia (Galicia) over the Flemish Cap or to have a gap between southwest Iberia and Newfoundland. 
Table 2. Geodynamic and timing constraints used in the kinematic reconstruction model.

\begin{tabular}{|c|c|c|c|c|}
\hline Domain & Area & Event/kinematics & Age (Ma) & References \\
\hline \multirow[t]{4}{*}{ Central Europe } & Germanic-Polish Basin & Continental rifting & $270(?)$ to 250 & $\begin{array}{l}\text { Evan et al. (1990); Van Wees et al. (2000); Evans et } \\
\text { al. (2003); Jackson et al. (2019) }\end{array}$ \\
\hline & Tornquist Zone & Right-lateral & Carboniferous to 250 (?) & Phillips et al. (2019) \\
\hline & & Left-lateral & 170 & Phillips et al. (2019) \\
\hline & & Right-lateral & 145 to 125 & Hippolyte (2002); Phillips et al. (2019) \\
\hline \multirow[t]{3}{*}{ Western Europe (France) } & Aquitaine Basin & Continental rifting & 270 (?) to $145 ; 125$ to 94 & $\begin{array}{l}\text { Curnelle (1983); Brunet (1984); Biteau et al. (2006); } \\
\text { Serrano et al. (2006) }\end{array}$ \\
\hline & Pyrenees & Continental rifting - left lateral & $270(?)$ to 145 & Curnelle (1983); Lucas (1985) \\
\hline & & Hyper-extended rifting - left-lateral & 125 to 94 & $\begin{array}{l}\text { Vielzeuf and Kornprobst (1984); Golberg and } \\
\text { Leyreloup (1990); Lagabrielle et al. (2010) }\end{array}$ \\
\hline \multirow[t]{4}{*}{ Iberia } & Basque-Cantabrian Basin & Left-lateral & 140 to 120 & $\begin{array}{l}\text { Quintana et al. (2015); Cámara (2017); Nirrengarten et } \\
\text { al. (2018) }\end{array}$ \\
\hline & Ebro Basin & Continental rifting & $270(?)$ to 145 & Vargas et al. (2009) \\
\hline & Iberian Range & Continental rifting - left lateral & $270(?)$ to 145 & Salas and Casas (1993) \\
\hline & & Hyper-extended rifting & 150 to 120 & $\begin{array}{l}\text { Salas and Casas (1993); Arche and López Gómez } \\
\text { (1996); Salas et al. (2001); Omodeo-Sale et al. (2017); } \\
\text { Rat et al. (2019) }\end{array}$ \\
\hline \multirow[t]{8}{*}{ Southern North Atlantic } & W Galicia & Continental rifting & 200 to 145 & Murillas et al. (1990) \\
\hline & & Lithospheric mantle exhumation & $135-115$ & Mohn et al. (2015) \\
\hline & & Initiation of oceanic spreading & $133-100$ & $\begin{array}{l}\text { Olivet (1996); Srivastava (2000); Schettino and Turco } \\
\text { (2009); Whitmarsh and Manatschal (2012) }\end{array}$ \\
\hline & Bay of Biscay & Mantle exhumation & 160 to 130 & Thinon et al. (2001); Tugend et al. (2014) \\
\hline & & Oceanic spreading & $124-112$ to 83 & $\begin{array}{l}\text { Thinon et al. (2002); Sibuet et al. (2004); Tugend et } \\
\text { al. (2015) }\end{array}$ \\
\hline & Southwest Iberia & Continental rifting & 200 to 161 & Murillas et al. (1990) \\
\hline & & Mantle exhumation & 145 & Sallàres et al. (2013) \\
\hline & & Initiation of oceanic spreading & 135-133 (Gorringe Bank) & Sallàres et al. (2013) \\
\hline \multirow[t]{3}{*}{ North Sea } & Arctic rift system & Continental rifting & $290(?)$ to 200 & Evans et al. (2003) \\
\hline & Rockall-Porcupine & Continental rifting & $230(?)$ to 112 & Evans et al. (2003) \\
\hline & Orphan & Continental rifting & 270 to 112 & $\begin{array}{l}\text { Nirrengarten et al. (2018); Hassaan et al. (2019); San- } \\
\text { doval et al. (2019) }\end{array}$ \\
\hline \multirow[t]{12}{*}{ Tethys and peri-Tethys } & S Alpine Tethys & Continental rifting & 270 to 220 & $\begin{array}{l}\text { Stampfli and Borel (2002); Schmid et al. (2008); Scis- } \\
\text { ciani and Esestime (2017) }\end{array}$ \\
\hline & & Breakup & 180 & $\begin{array}{l}\text { Schmid et al. (2008); Puga et al. (2011); Marroni et } \\
\text { al. (2017) }\end{array}$ \\
\hline & N Alpine Tethys & Oceanic spreading & $170-161$ & Bill et al. (2001); Schaltegger et al. (2002) \\
\hline & Paleotethys & Subduction & Early Carboniferous to 200 & $\begin{array}{l}\text { Stampfli et al. (2001); Stampfli and Borel (2002); Evans } \\
\text { et al. (2003) }\end{array}$ \\
\hline & Neotethys sensu stricto & $\begin{array}{l}\text { Oceanic spreading } \\
\text { Subduction }\end{array}$ & $\begin{array}{l}\text { Early Permian (?) } \\
\text { from } 156\end{array}$ & $\begin{array}{l}\text { Van Hinsbergen et al. (2019) } \\
\text { Schmid et al. (2008); Van Hinsbergen et al. (2019) }\end{array}$ \\
\hline & Ionian & $\begin{array}{l}\text { Continental rifting } \\
\text { Oceanic spreading }\end{array}$ & $\begin{array}{l}270 \text { to } 200(?) \\
\text { onset at } 180 ?\end{array}$ & $\begin{array}{l}\text { Muttoni et al. (2001); Tugend et al. (2019) } \\
\text { Tugend et al. (2019) }\end{array}$ \\
\hline & Vardar & Oceanic spreading & 180 to $160(?)$ & Channell and Kozur (1997) \\
\hline & & Subduction & 145 to 110 & Channell and Kozur (1997) \\
\hline & Pindos & Oceanic spreading & 250 to 200 & $\begin{array}{l}\text { Channel and Kozur (1997); Stampfli et al. (2001); } \\
\text { Schmid et al. (2008) }\end{array}$ \\
\hline & & Subduction & From Late Cretaceous & Channell and Kozur (1997) \\
\hline & Meliata & Oceanic spreading & 220 to 200 & $\begin{array}{l}\text { Channel and Kozur (1997); Stampfli et al. (2001); } \\
\text { Schmid et al. (2008) }\end{array}$ \\
\hline & & Subduction & 180 to $160(?)$ & Channell and Kozur (1997) \\
\hline \multirow[t]{2}{*}{ Central Atlantic } & & Continental rifting & 250 to 200 & Kneller et al. (2012) \\
\hline & & Oceanic spreading & 190 to 175 & Labails et al. (2010); Olyphant et al. (2017) \\
\hline
\end{tabular}



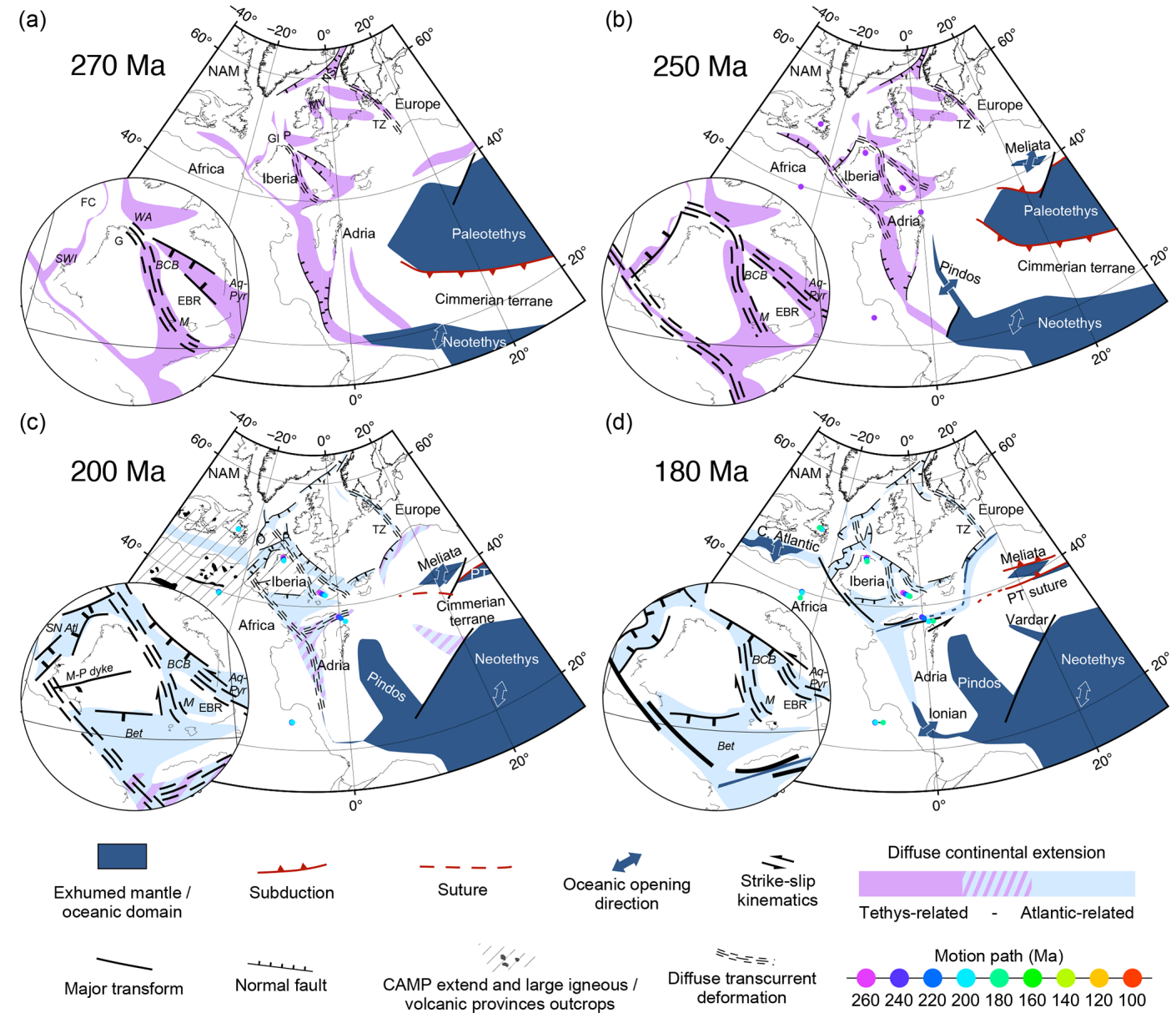

Figure 5. Large-scale reconstruction of the Tethys-Atlantic area for the $270 \mathrm{Ma}$ (a), $250 \mathrm{Ma}$ (b), $200 \mathrm{Ma}$ (c), and $180 \mathrm{Ma}$ (d) periods. Maps are in orthographic projection. Closeup shows the evolution of the Iberian plate and the Ebro continental block. Colored background shows diffuse or ill-defined deformation (extension or transtension) in the continents, associated with the evolution of the Tethys (Paleo- and Neotethys, purple) or the Atlantic (blue). At $200 \mathrm{Ma}$, the hatched area represents the CAMP extent. Aq-Pyr: Aquitaine-Pyrenean Basin; BCB: Basque-Cantabrian Basin; Bet: Betics Basin; EBR: Ebro; FC: Flemish Cap; G: Galicia; GI: Galicia Interior Basin; M: Maestrat; M-P: Messejana-Plascencia; MV: Midland Valley rift; NS: North Sea rift; O: Orphan Basin; P: Porcupine Basin; PT: Paleotethys; SN Atl: southern North Atlantic; SWI: southwest Iberia; TZ: Tornquist Zone; WA: Western Approaches.

\section{Kinematics of Iberia between the Atlantic and Tethys}

\subsection{Permian-Late Triassic (270-200 Ma)}

The Neotethys Ocean opening initiated in the early Permian in the northern Gondwana margin, resulting in the northward drift of the Cimmerian terrane and the subduction of the Paleozoic Paleotethys Ocean (Stampfli et al., 2001; Stampfli and Borel, 2002). This occurred contemporaneously with the establishment of the Carboniferous-Permian magmatic activity in the North Sea rift and Midland Valley rift areas (Evans et al., 2003; Heeremans et al., 2004; Upton et al., 2004).

As the Neotethys rift propagated westwards, diffuse continental rifting took place in the whole of western Europe defined by the position of the Paleozoic Variscan and Caledonian orogenic belts in the west, the Tornquist suture in the east and a diffuse transtensional transfer zone along the Africa-Iberia-Adria boundary (Fig. 5a). This is recorded by several late-Permian rift domains located in the southern North Atlantic (Rasmussen et al., 1998; Leleu et al., 2016), in the Adriatic (Scisciani and Esestime, 2017) in the North Sea (Hassaan et al., 2020), in the Germanic rift basins, including the Zechstein Basin (Evans, 1990; Van Wees et al., 2000; Jackson et al., 2019), and in Iberia (Figs. 2, 3, and 5a). A recent study (Sandoval et al., 2019) also showed a high preEarly Jurassic thinning in North Atlantic basins (e.g., Galicia Interior, Porcupine, and Orphan basins).

Back-arc extension associated with the subduction of the Paleotethys (Van Hinsbergen et al., 2020) (Fig. 5b) triggered the extension and formation of oceanic basins in the Pindos and Meliata domains during the Early (250 Ma) and Late Triassic (Carnian, 220 Ma), respectively (Channell and Kozur, 

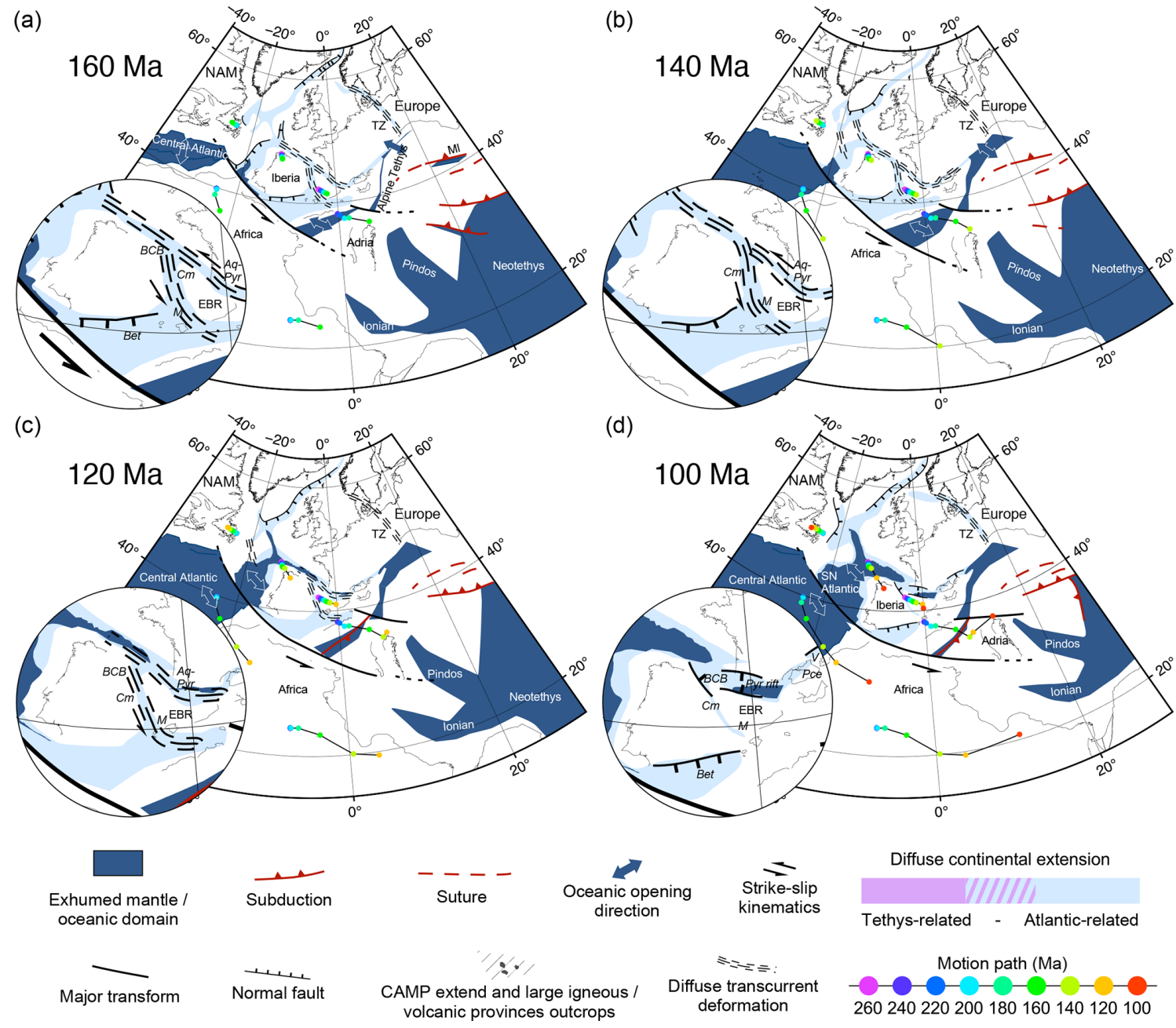

Figure 6. Large-scale reconstruction of the Tethys-Atlantic area for the $160 \mathrm{Ma}$ (a), $140 \mathrm{Ma}$ (b), $120 \mathrm{Ma}$ (c), and $100 \mathrm{Ma}$ (d) periods. Maps are in orthographic projection. Closeup shows the evolution of the Iberian plate and the Ebro continental block. Colored background shows diffuse or ill-defined deformation (extension or transtension) in the continents, associated with the evolution of the Tethys (Paleoand Neotethys, purple) or the Atlantic (blue). Aq-Pyr: Aquitaine-Pyrenean Basin; BCB: Basque-Cantabrian Basin; Bet: Betics Basin; Cm: Cameros; EBR: Ebro; M: Maestrat; Ml: Meliata; Pce: Provence Basin; V: Valaisan Basin; TZ: Tornquist Zone.

1997; Stampfli et al., 2001). As proposed by Schmid et al. (2008), the Pindos Ocean was probably a western branch of the Neotethys rather than a unique ocean. The strike-slip reactivation of the Tornquist Zone could also be a far-field effect of Paleotethys closure, as suggested by Phillips et al. (2018).

During the Late Triassic-Early Jurassic (Fig. 5c-d) the opening of the Ionian Basin (Tugend et al., 2019) triggers northward displacement of Adria relative to Iberia and Africa and induces transtension between Adria and Iberia. This is consistent with Triassic basins of eastern Betics and Catalonia that developed at the emplacement of the future Alpine Tethys, the rifting of which started from the Late Triassic (220 Ma) (Stampfli and Borel, 2002; Schmid et al., 2008). The large rift-related subsidence in the Iberian basins (Fig. 3b) is kinematically consistent with the stretching lin- eations documented from Triassic strata (Soto et al., 2019). Ebro is already individualized from Iberia and moved eastwards relative to Iberia and Europe through right-lateral and left-lateral strike-slip movements, respectively.

\subsection{Early Jurassic (200-160 Ma)}

This period marks a gradual change from Tethyan-dominated to Atlantic-dominated tectonism in Iberia. As the Neotethys propagated in the Vardar Ocean, the Pindos and Meliata oceans started to close (Fig. 5c) (Channell and Kozur, 1997). Major dynamic changes occurred with the CAMP event (Olsen, 1997; Marzoli et al., 1999; McHone, 2000; Leleu et al., 2016; Peace et al., 2019b) that led to breakup in the central Atlantic Ocean during the 190-175 Ma interval (Pliensbachian-Toarcian) (Fig. 5c-d) according to Labails 
et al. (2010) and Olyphant et al. (2017). The propagation of the central Atlantic rift northwards caused extension to propagate in the southern North Atlantic (Murillas et al., 1990; Leleu et al., 2016) and laterally, eastward in the Alpine Tethys (Schmid et al., 2008; Marroni et al., 2017) by some reactivation of Triassic Neotethyan rift structures. Evidence for nearly synchronous intrusions of MORB-type gabbro, in a western branch of the Alpine Tethys, is described at $180 \mathrm{Ma}$ in the internal zones of eastern Betics (Puga et al., 2011), associated with the rapid subsidence in the Betics (Fig. 3b). However, whether this is related to incipient oceanic spreading or magmatism in a hyper-extended margin is controversial. By contrast, both the thermal and stratigraphic evolutions (also Fig. 2) suggest that central Iberia remained little affected by the propagation of the Early Jurassic Atlantic rift Iberian basins (Aurell et al., 2019; Rat et al., 2019). A kinematic change from oblique to orthogonal E-W extension in the Alpine Tethys is marked by the onset of oceanic spreading between the Bajocian-Bathonian (170-166 Ma) and the Oxfordian (161 Ma) as suggested by the ages of MORB magmatism in the Alps (Schaltegger et al., 2002) and first postrift sediments (Bill et al., 2001). As such the Jurassic Alpine Tethys has temporal and genetic affinities with the Atlantic Ocean evolution rather than the Neotethys. The required differential movement between the opening of the Alpine oceanic domains, and the central Atlantic and the closure of the Neotethys and short-lived Vardar Oceans from $160 \mathrm{Ma}$ onward induced the reactivation of the former diffuse transfer zone between Iberia and Africa into a localized transform plate boundary (Fig. 6a).

\subsection{Late Jurassic-Early Cretaceous (160-100 Ma)}

A major tectonic change occurred in the Late Jurassic-Early Cretaceous when the southernmost North Atlantic successfully rifted the continental domain located offshore of southwest Iberia in present-day coordinates (between 160 and $100 \mathrm{Ma}$; Fig. 6), as recorded by mantle exhumation and subsequent oceanic spreading at 147 and 135-133 Ma, respectively, in Gorringe Bank (Sallarès et al., 2013). Oceanic opening then migrated northward, as attested by mantle exhumation and oceanic offshore of southwest Galicia between 139.8 and $129.4 \mathrm{Ma}$ (Mohn et al., 2015) and 121-112 Ma (Bronner et al., 2011; Vissers and Meijer, 2012) (Fig. 6b). At that time, the east-directed movement of Iberia relative to Ebro induced left-lateral transtensional faulting in a corridor shaped by the Iberian basins (Tugend et al., 2015; Aurell et al., 2019; Rat et al., 2019). We further infer a residual strike-slip movement between Ebro and Europe in the Pyrenean basins until the mid-Cretaceous (118 Ma) when the Bay of Biscay opened and the rotation of Iberia occurred (Sibuet et al., 2004; Barnett-Moore et al., 2016). The eastwards motion of Iberia relative to Adria resulted in the closure of the southern Alpine Tethys (Fig. 6c). Eastward rotation of Africa induces subduction along the northern Neotethyan margin (Schmid et al., 2008) (Fig. 6b-d).

Until $120 \mathrm{Ma}$ (Early Cretaceous) eastward accommodation space is constantly created by the formation of rift segments in the southwest Alpine domain (Valaisan domain and southeast basins of France) and then in the Provence domains (Tavani et al., 2018). In the southern part of the Western Alps, reactivation of Tethyan normal faults are shown to be Late Jurassic-Early Cretaceous in age (Tavani et al., 2018). At $110 \mathrm{Ma}$, deformation migrates in the South Provence Basin making a straighter continuity of the Pyrenean system toward the east (Tavani et al., 2018).

\section{Implications for strike-slip movements and the Europe-Iberia plate boundary}

\subsection{Amount of strike-slip displacement}

Table 3 summarizes the timing, amounts, and sense of strikeslip component of the Ebro kinematics relative to Europe and Iberia inferred from our model. Our reconstructions suggest a total left-lateral strike-slip movement of $278 \mathrm{~km}$ between Europe and Ebro. During the late-Permian-Triassic period (Fig. 5a-c, 270-200 Ma), $90 \mathrm{~km}$ was accommodated. During the Jurassic (Figs. 5c-d and 6a-b, 200-140 Ma), $86 \mathrm{~km}$ was accommodated. We quantify 99 and $19 \mathrm{~km}$ for the 140 120 and $120-100 \mathrm{Ma}$ time intervals, respectively, leading to a total of $128 \mathrm{~km}$ of strike-slip movement during the Lower Cretaceous, in the range of amounts deduced from offshore and onshore geological observations (Olivet, 1996; Canérot, 2016). By $118 \mathrm{Ma}$, most of the strike-slip faulting is terminated as extension became orthogonal and Ebro is close to its present-day position (Jammes et al., 2009; Mouthereau et al., 2014). The maximum strain rate of $5 \mathrm{~km} \mathrm{Myr}^{-1}$ is obtained for the 140-120 Ma time interval, revealing progressive strain localization in the Pyrenean basins before mantle exhumation (Jammes et al., 2009; Lagabrielle et al., 2010; Mouthereau et al., 2014; Tugend et al., 2014).

The Iberia-Ebro boundary has played as right-lateral and left-lateral kinematics. The rapid eastward displacement of Ebro during the late-Permian to Late Jurassic period (Figs. 5 and 6) induces a total of $67 \mathrm{~km}(12,33,17$, and $5 \mathrm{~km}$ during the 270-250, 250-200, 200-180, and 180-160 Ma time interval, respectively) right-lateral strike-slip between Ebro and Iberia (i.e., Galicia). This displacement has been partitioned with extension within the Iberian basins along a NWdirected intra-continental deformation corridor. This is consistent with stretching markers in Triassic rocks in this area (Soto et al., 2019). From 160 to $100 \mathrm{Ma}$, the northward propagation of the central Atlantic spreading ridge into the southern North Atlantic resulted in a net left-lateral slip of $245 \mathrm{~km}$ and increasing strain rates of up to $9 \mathrm{~km} \mathrm{Myr}^{-1}$, indicating that the southern Ebro boundary became the main tectonic 
Table 3. Quantification of strike-slip displacement between the European and Ebro and between the Iberia (Galicia) and Ebro.

\begin{tabular}{|c|c|c|c|c|c|c|}
\hline \multirow[b]{2}{*}{ Age (Ma) } & \multicolumn{3}{|c|}{ Iberia-Ebro } & \multicolumn{3}{|c|}{ Europe-Ebro } \\
\hline & Amount (km) & Rate $\left(\mathrm{km} \mathrm{Ma}^{-1}\right)$ & Direction & Amount $(\mathrm{km})$ & Rate $\left(\mathrm{km} \mathrm{Ma}^{-1}\right)$ & Direction \\
\hline $270-250$ & 12 & 0.6 & right-lateral & 16 & 0.8 & left-lateral \\
\hline $250-200$ & 33 & 0.7 & right-lateral & 74 & 1.5 & left-lateral \\
\hline $200-180$ & 17 & 0.9 & right-lateral & 19 & 1.0 & left-lateral \\
\hline $180-160$ & 5 & 0.3 & right-lateral & 24 & 1.2 & left-lateral \\
\hline $160-140$ & 4 & 0.2 & left-lateral & 43 & 2.2 & left-lateral \\
\hline $140-120$ & 62 & 3.1 & left-lateral & 99 & 5.0 & left-lateral \\
\hline $120-100$ & 179 & 9.0 & left-lateral & 19 & 1.0 & left-lateral \\
\hline \multirow[t]{2}{*}{ Total } & 67 km (right-lateral) & & & & & \\
\hline & 245 km (left-lateral) & & & 278 km (left-lateral) & & \\
\hline
\end{tabular}

boundary in Iberia, accommodating eastwards displacement of Iberia into the Alpine Tethys region.

The cumulated left-lateral displacement from both rift systems, corrected for the right-lateral displacement in the Iberian basins, is $456 \mathrm{~km}$, consistent with the absolute 400 $500 \mathrm{~km}$ required from the closure of the Atlantic between Iberia and Newfoundland.

\subsection{Strike-slip structures in the intra-Iberian basins}

Despite the requirement of $245 \mathrm{~km}$ left-lateral strike-slip displacement along the Iberia-Ebro boundary from 160 to $100 \mathrm{Ma}$, there is no simple geological evidence in support of a unique major crustal-scale fault in the Iberian RangeBasque-Cantabrian Basin system.

Several studies have suggested that a left-lateral shear zone can be recognized along the Iberian Range and the BasqueCantabrian rifts system. Geological evidence includes the High Tagus Fault in the Iberian Range (Aldega et al., 2019; Aurell et al., 2019) and the Ventaniella Fault in the BasqueCantabrian region (e.g., Tavani et al., 2011). The latter fault is often considered in recent reconstructions to accommodate the Iberia-Ebro movement alone (Tugend et al., 2015; Nirrengarten et al., 2018). However, the estimated left-lateral displacement along the Ventaniella Fault is only in the order of magnitude of a few kilometers (Tavani et al., 2011) and therefore cannot be used as a North Pyrenean Fault equivalent.

In the Basque-Cantabrian Basin, the Ventaniella Fault is part of a NW-SE fault system that acted as left-lateral shear zone during the Late Jurassic-Early Cretaceous and has been subsequently inverted with a right-lateral kinematic during the Cenozoic (De Vicente et al., 2011; Tavani et al., 2011; Cámara and Flinch, 2017). These faults have a Triassic origin (Tavani and Granado, 2015). Tectonic activity along these faults gets younger NE-ward (Ubierna fault: Late JurassicEarly Cretaceous; Zamanza-Oña fault: Early-Middle Cretaceous; salt tectonics in the center of the Basin, Cámara and
Flinch, 2017). We suggest the Iberia-Ebro displacement to have possibly been distributed along these structures.

The role of the weak Triassic evaporites in efficiently decoupling deformation in the pre-salt basement from the thinskinned extension in sedimentary cover has been emphasized largely in the Pyrenees (e.g., Grool et al., 2019; Duretz et al., 2019; Jourdon et al., 2020; Lagabrielle et al., 2020). Salt tectonics has also been suggested to have been particularly significant from the Jurassic through the Early Cretaceous in Mesozoic basins that shaped the NW-directed boundary between Ebro and Iberia, including the Basque-Cantabrian Basin (Cámara and Flinch, 2017), Parentis Basin (Ferrer et al., 2012), Cameros Basin (Rat et al., 2019), and Maestrat Basin (Vergés et al., 2020). The surface expression of the crustal strike-slip movements is inferred to have been limited in supra-salt layers.

The mechanism responsible for the independent movement of Ebro relative to Europe and Iberia prior to the opening of the southern North Atlantic remains unclear. The most likely hypothesis is that before the opening of the Alpine Tethys, the Ebro continental block was related to the regional eastward rotation of the Africa-Adria system. This rotation caused Ebro to move eastward, accommodating left-lateral and right-lateral strike-slip kinematics in the Pyrenean and Iberian basins, respectively.

\section{Conclusions}

To resolve several long-lasting problems of the Mesozoic kinematics of Iberia, we propose to better account for deformation associated with late-Permian-Triassic rifting and the role of the Ebro continental block in accommodating complex strain partitioning along the Iberia-Europe plate boundary and replace Iberia in a refined plate reconstruction between the Atlantic and Tethys domains. We show that (1) left-lateral strike-slip movement did occur in the Pyrenees from the late Permian to the Early Cretaceous but ended as the Bay of Biscay opened; (2) late-Permian-Triassic ex- 
tension in the Atlantic and Iberia (including Ebro) is key to quantifying the strike-slip movement in Iberia that is otherwise not well resolved from the geological constraints in Iberian basins and from full-fit reconstructions in the Jurassic. Salt tectonics that decouples syn-rift Iberian basins' evolution from their basement likely explains the lack of geological constraints.

The diffuse deformation across the Iberia-Europe plate boundary prior to oceanic spreading in the Bay of Biscay and hyper-extension in the Pyrenees appears to result mainly from transcurrent deformation partitioned with subordinate fault-perpendicular extension. The major intra-Iberia NWtrending strike-slip fault system outlined by spatially disconnected rift basins (Basque-Cantabrian, Cameros, Maestrat, and Columbrets basins) played a significant role in the Late Jurassic-Early Cretaceous, in addition to the North Pyrenean rift system.

By integrating the position of Iberia in the Tethyan and Atlantic evolution and propagating the effect of the eastward movement of Iberia into the Alpine Tethys, our reconstructions further imply that (1) Ebro was part of Adria before the onset of the Alpine Tethys opening, (2) the southern Alpine Tethys started to close in the Early Cretaceous (145 to $100 \mathrm{Ma}$ ), and (3) the boundary between Iberia and Africa localized as a transform plate boundary at $160 \mathrm{Ma}$, connecting the Alpine oceanic domains with the central Atlantic.

Data availability. This study is based on data compilation. Data used in this study can be found in the appropriate references. Kinematic model files are available online in the Supplement.

Supplement. The supplement related to this article is available online at: https://doi.org/10.5194/se-11-1313-2020-supplement.

Author contributions. This article was mostly written by PA and FM. PA carried out the compilation of data, interpretation, and kinematic model and figures, in tight collaboration with FM. The text benefits from the expertise and contribution of EM and RA.

Competing interests. The authors declare that they have no conflict of interest.

Acknowledgements. We acknowledge the members of the OROGEN scientific project for support and discussions, in particular Sylvain Calassou, Olivier Vidal, Isabelle Thinon, Laure MoenMaurel, Mary Ford, Laurent Jolivet, Gianreto Manatschal and Gianluca Frasca. We thank Alexander L. Peace and an anonymous referee for very constructive comments and suggestions that led us to improve the paper.
Financial support. This research has been supported by the Centre National de la Recherche Scientifique (CNRS-INSU), the French Geological Survey (BRGM), and Total through the OROGEN project, as a post-doctoral grant of Paul Angrand.

Review statement. This paper was edited by Mark Allen and reviewed by Alexander L. Peace and one anonymous referee.

\section{References}

Aldega, L., Viola, G., Casas-Sainz, A., Marcén, M., Román-Berdiel, T., and van der Lelij, R.: Unraveling Multiple Thermotectonic Events Accommodated by Crustal-Scale Faults in Northern Iberia, Spain: Insights From K-Ar Dating of Clay Gouges, Tectonics, 38, 3629-3651, https://doi.org/10.1029/2019TC005585, 2019.

Alvaro, M., del Villar, R. C., and Vegas, R.: Un modelo de evolución geotectónica para la Cadena Celtibérica, Acta Geológica Hispánica, 14, 172-177, 1979.

Arche, A. and López Gómez, J.: Origin of the Permian-Triassic Iberian basin, central-eastern Spain, Tectonophysics, 266, 443464, 1996.

Aurell, M., Fregenal-Martínez, M., Bádenas, B., Muñoz-García, M. B., Élez, J., Meléndez, N., and de Santisteban, C.: Middle Jurassic-Early Cretaceous tectono-sedimentary evolution of the southwestern Iberian Basin (central Spain): Major palaeogeographical changes in the geotectonic framework of the Western Tethys, Earth-Sci. Rev., 199, 102983, https://doi.org/10.1016/j.earscirev.2019.102983, 2019.

Avedik, F.: Seismic Structure of the Western Approaches and the South Armorican Continental Shelf and Its Geological Interpretation., Geol, 1, 29-43, 1975.

Azambre, B., Rossy, M., and Lago, M.: Caractéristiques pétrologiques des dolérites tholéiitiques $\mathrm{d}$ ' âge triasique ( ophites ) du domaine pyrénéen, B. Minéral., 110, 379-396, 1987.

Balkwill, H. R. and Legall, F. D.: Whale Basin, Offshore Newfoundland: Extension and Salt Diapirism, chap. 15, North American Margins, 1989.

Barnett-Moore, N., Hosseinpour, M., and Maus, S.: Assessing discrepancies between previous plate kinematic models of Mesozoic Iberia and their constraints, Tectonics, 35, 1843-1862, https://doi.org/10.1002/2015TC004019, 2016.

Bestani, L., Espurt, N., Lamarche, J., Bellier, O., and Hollender, F.: Reconstruction of the Provence Chain evolution, southeastern France, Tectonics, 35, 1506-1525, https://doi.org/10.1002/2016TC004115, 2016.

Bill, M., O'Dogherty, L., Guex, J., Baumgartner, P. O., and Masson, H.: Radiolarite ages in AlpineMediterranean ophiolites: Constraints on the oceanic spreading and the Tethys-Atlantic connection, B. Geol. Soc. Am., 113, 129-143, https://doi.org/10.1130/00167606(2001)113<0129:RAIAMO>2.0.CO;2, 2001.

Biteau, J. J., Le Marrec, A., Le Vot, M., and Masset, J. M.: The Aquitaine Basin, Petroleum Geoscience, 12, 247-273, https://doi.org/10.1144/1354-079305-674, 2006.

Bronner, A., Sauter, D., Manatschal, G., Péron-pinvidic, G., and Munschy, M.: Magmatic breakup as an explanation for magnetic 
anomalies at magma-poor rifted margins, Nat. Geosci., 4, 549553, https://doi.org/10.1038/nphys1201, 2011.

Brunet, M. F.: Subsidence history of the Aquitaine basin determined from subsidence curves, Geol. Mag., 121, 421-428, https://doi.org/10.1017/S0016756800029952, 1984.

Cámara, P.: Salt and Strike-Slip Tectonics as Main Drivers in the Structural Evolution of the Basque-Cantabrian Basin, Spain, in: Permo-Triassic Salt Provinces of Europe, North Africa and the Atlantic Margins, edited by: Soto, J. I., Flinch, J. F., and Gabor, B., Elsevier, 371-393, https://doi.org/10.1016/B978-0-12809417-4.00018-5, 2017.

Cámara, P. and Flinch, J.: The southern Pyrenees: a salt-based fold-and-thrust belt, in: Permo-Triassic Salt Provinces of Europe, North Africa and the Atlantic Margins, edited by: Soto, J. I., Flinch, J. F., and Gabor, B., Elsevier, 395-415, https://doi.org/10.1016/B978-0-12-809417-4.00019-7, 2017.

Canérot, J.: The Iberian plate: Myth or reality?, Boletin Geologico y Minero, 127, 563-574, 2016.

Cerbiá, J. M., López-Ruiz, J., Doblas, M., Martins, L. T., and Munha, J.: Geochemistry of the Early Jurassic MessejanaPlasencia dyke (Portugal-Spain); Implications on the Origin of the Central Atlantic Magmatic Province, J. Petrol., 44, 547-568, https://doi.org/10.1093/petrology/44.3.547, 2003.

Channell, J. E. and Kozur, H. W.: How many oceans? Meliata, Vardar, Pindos oceans in Mesozoic Alpine paleogeography, Geology, 25, 183-186, https://doi.org/10.1130/00917613(1997)025<0183:HMOMVA>2.3.CO;2, 1997.

Chevrot, S., Sylvander, M., Diaz, J., Martin, R., Mouthereau, F., Manatschal, G., Masini, E., Calassou, S., Grimaud, F., Pauchet, H., and Ruiz, M.: The non-cylindrical crustal architecture of the Pyrenees, Sci. Rep.-UK, 8, 1-8, https://doi.org/10.1038/s41598018-27889-x, 2018.

Choukroune, P. and Mattauer, M.: Tectonique des plaques et Pyrenees; sur le fonctionnement de la faille transformante nordpyreneenne; comparaisons avec des modeles actuels, B. Soc. Géol. Fr., 7, 689-700, 1978.

Coltice, N., Bertrand, H., Rey, P., Jourdan, F., Phillips, B. R., and Ricard, Y.: Global warming of the mantle beneath continents back to the Archaean, Gondwana Res., 15, 254-266, https://doi.org/10.1016/j.gr.2008.10.001, 2009.

Curnelle, R.: Evolution structuro-sedimentaire du Trias et de l'Infra-Lias d'Aquitaine., Bulletin des Centres de Recherches Exploration-Production Elf-Aquitaine, 7, 69-99, 1983.

Debroas, E. J.: Modèle de bassin triangulaire à l'intersection de décrochements divergents pour le fossé albo-cénomanien de la Ballongue (Zone Nord-Pyrénéenne, France), B. Soc. Géol. Fr., 8, 887-898, 1987.

Debroas, E. J.: Le Flysch noir albo-cénomanien témoin de la structuration albienne à sénonienne de la Zone nord-pyrénéenne en Bigorre (Hautes-Pyrénées, France), B. Soc. Géol. Fr., 8, 273 285, 1990.

Denèle, Y., Paquette, J. L., Olivier, P., and Barbey, P.: Permian granites in the Pyrenees: The Aya pluton (Basque Country), Terra Nova, 24, 105-113, https://doi.org/10.1111/j.13653121.2011.01043.x, 2012.

Denèle, Y., Laumonier, B., Paquette, J. L., Olivier, P., Gleizes, G., and Barbey, P.: Timing of granite emplacement, crustal flow and gneiss dome formation in the Variscan segment of the Pyrenees, Geol. Soc. Spec. Publ., 405, 265-287, https://doi.org/10.1144/SP405.5, 2014.

Deptuck, M. E. and Kendell, K. L.: A review of Mesozoic-Cenozoic salt tectonics along the Scotian margin, eastern Canada, in: Permo-Triassic Salt Provinces of Europe, North Africa and the Atlantic Margins, Elsevier, 287-312, 2017.

de Saint Blanquat, M.: La faille normale ductile du massif du Saint Barthélémy. Evolution hercynienne des massifs nord-pyrénéens catazonaux considérée du point de vue de leur histoire thermique, Geodin. Acta, 6, 59-77, 1993.

De Saint Blanquat, M., Lardeaux, J. M., and Brunel, M.: Petrological arguments for high-temperature extensional deformation in the Pyrenean Variscan crust (Saint Barthélémy Massif, Ariège, France), Tectonophysics, 177, 245-262, 1990.

De Vicente, G., Cloetingh, S. A., Van Wees, J. D., and Cunha, P. P.: Tectonic classification of Cenozoic Iberian foreland basins, Tectonophysics, 502, 38-61, https://doi.org/10.1016/j.tecto.2011.02.007, 2011.

Domeier, M. and Torsvik, T. H.: Plate tectonics in the late Paleozoic, Geosci. Front., 5, 303-350, https://doi.org/10.1016/j.gsf.2014.01.002, 2014.

Doré, A. G.: The structural foundation and evolution of Mesozoic seaways between Europe and the Arctic, Palaeogeogr. Palaeocl., 87, 441-492, 1991.

Doré, A. G., Lundin, E. R., Jensen, L. N., Birkeland, Ø., Eliassen, P. E., and Fichler, C.: Principal tectonic events in the evolution of the northwest European Atlantic margin, in: Geological society, London, petroleum geology conference series, Geological Society of London, 5, 41-61, 1999.

Duretz, T., Asti, R., Lagabrielle, Y., Brun, J. P., Jourdon, A., Clerc, C., and Corre, B.: Numerical modelling of Cretaceous Pyrenean Rifting: The interaction between mantle exhumation and syn-rift salt tectonics, Basin Res., 1-16, https://doi.org/10.1111/bre.12389, 2019.

Espurt, N., Angrand, P., Teixell, A., Labaume, P., Ford, M., De Saint Blanquat, M., and Chevrot, S.: Crustal-scale balanced cross-section and restorations of the Central Pyrenean belt (Nestes-Cinca transect): Highlighting the structural control of Variscan belt and Permian-Mesozoic rift systems on mountain building, Tectonophysics, 764, 25-45, https://doi.org/10.1016/j.tecto.2019.04.026, 2019.

Etheve, N., Mohn, G., Frizon de Lamotte, D., Roca, E., Tugend, J., and Gómez-Romeu, J.: Extreme Mesozoic Crustal Thinning in the Eastern Iberia Margin: The Example of the Columbrets Basin (Valencia Trough), Tectonics, 37, 636-662, https://doi.org/10.1002/2017TC004613, 2018.

Evans, C. D. R.: United Kingdom offshore regional report: the geology of the western English Channel and its western approaches, Tech. rep., British Geological Survey, London, 1990.

Evans, D.: The Millennium Atlas: Petroleum Geology of the Central and Northern North Sea, Geological Society of London, London, 2003.

Fabriès, J., Lorand, J. P., Bodinier, J. L., and Dupuy, C.: Evolution of the upper mantle beneath the pyrenees: Evidence from orogenic spinel lherzolite massifs, J. Petrol., 55-76, https://doi.org/10.1093/petrology/Special_Volume.2.55, 1991.

Fabriès, J., Lorand, J. P., and Bodinier, J. L.: Petrogenetic evolution of orogenic lherzolite massifs in the cen- 
tral and western Pyrenees, Tectonophysics, 292, 145-167, https://doi.org/10.1016/S0040-1951(98)00055-9, 1998.

Fernández, O.: The Jurassic evolution of the Africa-Iberia conjugate margin and its implications on the evolution of the Atlantic-Tethys triple junction, Tectonophysics, 750, 379-393, https://doi.org/10.1016/j.tecto.2018.12.006, 2019.

Ferrer, O., Jackson, M. P., Roca, E., and Rubinat, M.: Evolution of salt structures during extension and inversion of the Offshore Parentis Basin (Eastern Bay of Biscay), Geol. Soc. Spec. Publ., 363, 361-380, https://doi.org/10.1144/SP363.16, 2012.

Ganne, J., Feng, X., Rey, P., and De Andrade, V.: Statistical petrology reveals a link between supercontinents cycle and mantle global climate, Am. Mineral., 101, 2768-2773, https://doi.org/10.2138/am-2016-5868, 2016.

Glennie, K. W., Higham, J., and Stemmerik, L.: Permian, in: The millennium atlas; petroleum geology of the central and northern North Sea, edited by: Evans, D., Graham, C., Armour, A., and Bathurst, P., chap. 8, 91-103, Geological Society of London, London, 2003.

Golberg, J. M. and Leyreloup, A. F.: High temperature-low pressure Cretaceous metamorphism related to crustal thinning (Eastern North Pyrenean Zone, France), Contributions to Mineralogy and Petrology, 104, 194-207, https://doi.org/10.1007/BF00306443, 1990.

Goldsmith, P. J., Hudson, G., and Van Veen, P.: Triassic, in: The millennium atlas; petroleum geology of the central and northern North Sea, edited by: Evans, D., Graham, C., Armour, A., and Bathurst, P., 105-127, Geological Society of London, London, 2003.

Grool, A. R., Huismans, R. S., and Ford, M.: Salt décollement and rift inheritance controls on crustal deformation in orogens, Terra Nova, 31, 562-568, https://doi.org/10.1111/ter.12428, 2019.

Hafid, M.: Triassic-early Liassic extensional systems and their Tertiary inversion, Essaouira Basin (Morocco), Mar. Petrol. Geol., 17, 409-429, https://doi.org/10.1016/S0264-8172(98)00081-6, 2000.

Handy, M. R., M. Schmid, S., Bousquet, R., Kissling, E., and Bernoulli, D.: Reconciling plate-tectonic reconstructions of Alpine Tethys with the geological-geophysical record of spreading and subduction in the Alps, Earth-Sci. Rev., 102, 121-158, https://doi.org/10.1016/j.earscirev.2010.06.002, 2010.

Hanne, D., White, N., and Lonergan, L.: Subsidence analyses from the Betic Cordillera, southeast Spain, Basin Res., 15, 1-21, https://doi.org/10.1046/j.1365-2117.2003.00192.x, 2003.

Hassaan, M., Inge, J., Helge, R., and Tsikalas, F.: Carboniferous graben structures, evaporite accumulations and tectonic inversion in the southeastern Norwegian Barents Sea, Marine and Petroleum Geology, 112, 104038, https://doi.org/10.1016/j.marpetgeo.2019.104038, 2019.

Hassaan, M., Inge, J., Helge, R., and Tsikalas, F.: Carboniferous graben structures, evaporite accumulations and tectonic inversion in the southeastern Norwegian Barents Sea, Mar. Petrol. Geol., 112, 104038, https://doi.org/10.1016/j.marpetgeo.2019.104038, 2020.

Heeremans, M., Timmerman, M. J., Kirstein, L. A., and Faleide, J. I.: New constraints on the timing of late Carboniferous-early Permian volcanism in the central North Sea, Geol. Soc. Spec. Publ., 223, 177-193, 2004.
Heine, C., Zoethout, J., and Müller, R. D.: Kinematics of the South Atlantic rift, Solid Earth, 4, 215-253, https://doi.org/10.5194/se4-215-2013, 2013.

Jackson, C. A., Gawthorpe, R. L., Elliott, G. M., and Rogers, E. R.: Salt thickness and composition influence rift structural style, northern North Sea, offshore Norway, 514-538, https://doi.org/10.1111/bre.12332, 2019.

Jammes, S., Manatschal, G., Lavier, L., and Masini, E.: Tectonosedimentary evolution related to extreme crustal thinning ahead of a propagating ocean: Example of the western Pyrenees, Tectonics, 28, 1-24, https://doi.org/10.1029/2008TC002406, 2009.

Jourdon, A., Mouthereau, F., Pourhiet, L. L., and Callot, J. P.: Topographic and Tectonic Evolution of Mountain Belts Controlled by Salt Thickness and Rift Architecture, 39, 1-14, https://doi.org/10.1029/2019TC005903, 2020.

Kneller, E. A., Johnson, C. A., Karner, G. D., Einhorn, J., and Queffelec, T. A.: Inverse methods for modeling non-rigid plate kinematics: Application to mesozoic plate reconstructions of the Central Atlantic, Comput. Geosci., 49, 217-230, https://doi.org/10.1016/j.cageo.2012.06.019, 2012.

Labails, C., Olivet, J. L., Aslanian, D., and Roest, W. R.: An alternative early opening scenario for the Central Atlantic Ocean, Earth Planet. Sc. Lett., 297, 355-368, https://doi.org/10.1016/j.eps1.2010.06.024, 2010.

Lagabrielle, Y., Labaume, P., and De Saint Blanquat, M.: Mantle exhumation, crustal denudation, and gravity tectonics during Cretaceous rifting in the Pyrenean realm (SW Europe): Insights from the geological setting of the lherzolite bodies, Tectonics, 29, 126, https://doi.org/10.1029/2009TC002588, 2010.

Lagabrielle, Y., Asti, R., Duretz, T., Clerc, C., Fourcade, S., Teixell, A., Labaume, P., Corre, B., and Saspiturry, N.: A review of cretaceous smooth-slopes extensional basins along the Iberia-Eurasia plate boundary: How pre-rift salt controls the modes of continental rifting and mantle exhumation, Earth-Sci. Rev., 201, 103071, https://doi.org/10.1016/j.earscirev.2019.103071, 2020.

Lago, M., Arranz, E., Pocoví, A., Galé, C., and Gil-Imaz, A.: Lower Permian magmatism of the Iberian Chain, Central Spain, and its relationship to extensional tectonics, Geol. Soc. Spec. Publ., 223, 465-490, https://doi.org/10.1144/GSL.SP.2004.223.01.20, $2004 \mathrm{a}$.

Lago, M., Arranz, E., Pocoví, A., Galé, C., and Gil-Imaz, A.: Permian magmatism and basin dynamics in the southern Pyrenees: a record of the transition from late Variscan transtension to early Alpine extension, Geol. Soc. Spec. Publ., 223, 439-464, 2004b.

Leleu, S., Hartley, A. J., van Oosterhout, C., Kennan, L., Ruckwied, K., and Gerdes, K.: Structural, stratigraphic and sedimentological characterisation of a wide rift system: The Triassic rift system of the Central Atlantic Domain, Earth-Sci. Rev., 158, 89-124, https://doi.org/10.1016/j.earscirev.2016.03.008, 2016.

Lucas, C.: Le grès rouge du versant nord des Pyrénées: essai sur la géodynamique de dépôts continentaux du Permien et du Trias, $\mathrm{PhD}$ thesis, Université de Toulouse, Toulouse, 1985.

Malavieille, J., Guihot, P., Costa, S., Lardeaux, J. M., and Gardien, V.: Collapse of the thickened Variscan crust in the French Massif Central: Mont Pilat extensional shear zone and St. Etienne Late Carboniferous basin, Tectonophysics, 177, 139-149, 1990.

Marroni, M., Meneghini, F., and Pandolfi, L.: A Revised Subduction Inception Model to Explain the Late Cretaceous, DoubleVergent Orogen in the Precollisional Western Tethys: Evi- 
dence From the Northern Apennines, Tectonics, 36, 2227-2249, https://doi.org/10.1002/2017TC004627, 2017.

Marzoli, A., Renne, P. R., Piccirillo, E. M., Ernesto, M., Bellieni, G., and De Min, A.: Extensive 200-million-year-old continental flood basalts of the Central Atlantic Magmatic Province, Science, 284, 616-618, https://doi.org/10.1126/science.284.5414.616, 1999.

Masini, E., Manatschal, G., Tugend, J., Mohn, G., and Flament, J. M.: The tectono-sedimentary evolution of a hyper-extended rift basin: The example of the Arzacq-Mauléon rift system (Western Pyrenees, SW France), Int. J. Earth Sci., 103, 1569-1596, https://doi.org/10.1007/s00531-014-1023-8, 2014.

McHone, J. G.: Non-plume magmatism and rifting during the opening of the central Atlantic Ocean, Tectonophysics, 316, 287-296, https://doi.org/10.1016/S0040-1951(99)00260-7, 2000.

McKenzie, D.: Some remarks on the development of sedimentary basins, Earth Planet. Sc. Lett., 40, 25-32, https://doi.org/10.1016/0012-821X(78)90071-7, 1978.

McKenzie, D., Daly, M. C., and Priestley, K.: The lithospheric structure of Pangea, Geology, 43, 783-786, https://doi.org/10.1130/G36819.1, 2015.

McKie, T.: Paleogeographic evolution of latest Permian and Triassic salt basins in Northwest Europe, in: Permo-Triassic Salt Provinces of Europe, North Africa and the Atlantic Margins, Elsevier, 159-173, 2017.

McQuarrie, N. and Van Hinsbergen, D. J.: Retrodeforming the Arabia-Eurasia collision zone: Age of collision versus magnitude of continental subduction, Geology, 41, 315-318, https://doi.org/10.1130/G33591.1, 2013.

Mohn, G., Karner, G. D., Manatschal, G., and Johnson, C. A.: Structural and stratigraphic evolution of the IberiaNewfoundland hyper-extended rifted margin: A quantitative modelling approach, Geol. Soc. Spec. Publ., 413, 53-89, https://doi.org/10.1144/SP413.9, 2015.

Mouthereau, F., Filleaudeau, P. Y., Vacherat, A., Pik, R., Lacombe, O., Fellin, M. G., Castelltort, S., Christophoul, F., and Masini, E.: Placing limits to shortening evolution in the Pyrenees: Role of margin architecture and implications for the Iberia/Europe convergence, Tectonics, 33, 2283-2314, https://doi.org/10.1002/2014TC003663, 2014.

Müller, D. R., Cannon, J., Qin, X., Watson, R. J., Gurnis, M., Williams, S., Pfaffelmoser, T., Seton, M., Russell, S. H., and Zahirovic, S.: GPlates: Building a Virtual Earth Through Deep Time, Geochem. Geophy. Geosy., 19, 2243-2261, https://doi.org/10.1029/2018GC007584, 2018.

Müller, D. R., Zahirovic, S., Williams, S. E., Cannon, J., Seton, M., Bower, D. J., Tetley, M. G., Heine, C., Le Breton, E., Liu, S., Russell, S. H., Yang, T., Leonard, J., and Gurnis, M.: A Global Plate Model Including Lithospheric Deformation Along Major Rifts and Orogens Since the Triassic, Tectonics, 38, 1884-1907, https://doi.org/10.1029/2018TC005462, 2019.

Müller, R. D., Sdrolias, M., Gaina, C., and Roest, W. R.: Age, spreading rates, and spreading asymmetry of the world's ocean crust, Geochem. Geophy. Geosy., 9, 1-19, https://doi.org/10.1029/2007GC001743, 2008.

Murillas, J., Mougenot, D., Boillot, G., Comas, M. C., Banda, E., and Mauffret, A.: Structure and evolution of the Galicia Interior Basin (Atlantic western Iberian continental margin), Tectonophysics, 184, 297-319, 1990.
Nirrengarten, M., Manatschal, G., Tugend, J., Kusznir, N. J., and Sauter, D.: Nature and origin of the J-magnetic anomaly offshore Iberia-Newfoundland: implications for plate reconstructions, Terra Nova, 29, 20-28, https://doi.org/10.1111/ter.12240, 2017.

Nirrengarten, M., Manatschal, G., Tugend, J., Kusznir, N. J., and Sauter, D.: Kinematic Evolution of the Southern North Atlantic: Implications for the Formation of Hyperextended Rift Systems, Tectonics, 37, 89-118, https://doi.org/10.1002/2017TC004495, 2018.

Olivet, J. L.: La cinématique de la plaque ibérique, Bulletin des centres de recherches exploration-production Elf-Aquitaine, 20, 131-195, 1996.

Olsen, P. E.: Stratigraphic Record of the Early Mesozoic Breakup of Pangea in the Laurasia-Gondwana Rift System, Annu. Rev. Earth Pl. Sc., 25, 337-401, https://doi.org/10.1146/annurev.earth.25.1.337, 1997.

Olyphant, J. R., Johnson, R. A., and Hughes, A. N.: Evolution of the Southern Guinea Plateau: Implications on GuineaDemerara Plateau formation using insights from seismic, subsidence, and gravity data, Tectonophysics, 717, 358-371, https://doi.org/10.1016/j.tecto.2017.08.036, 2017.

Omodeo-Salé, S., Salas, R., Guimerà, J., Ondrak, R., Mas, R., Arribas, J., Suárez-Ruiz, I., and Martinez, L.: Subsidence and thermal history of an inverted Late Jurassic-Early Cretaceous extensional basin (Cameros, North-central Spain) affected by very low- to low-grade metamorphism, Basin Res., 29, 156-174, https://doi.org/10.1111/bre.12142, 2017.

Ortí, F., Pérez-López, A., and Salvany, J. M.: Triassic evaporites of Iberia: Sedimentological and palaeogeographical implications for the western Neotethys evolution during the Middle Triassic-Earliest Jurassic, Palaeogeogr. Palaeocl., 471, 157-180, https://doi.org/10.1016/j.palaeo.2017.01.025, 2017.

Peace, A. L., Phethean, J., Franke, D., Foulger, G., Schiffer, C., Welford, J., McHone, G., Rocchi, S., Schnabel, M., and Doré, A.: A review of Pangaea dispersal and Large Igneous Provinces - In search of a causative mechanism, Earth-Sci. Rev., p. 102902, https://doi.org/10.1016/j.earscirev.2019.102902, 2019a.

Peace, A. L., Welford, J. K., Ball, P. J., and Nirrengarten, M.: Deformable plate tectonic models of the southern North Atlantic, J. Geodyn., 128, 11-37, https://doi.org/10.1016/j.jog.2019.05.005, 2019b.

Pereira, R., Alves, T. M., and Mata, J.: Alternating crustal architecture in West Iberia: A review of its significance in the context of NE atlantic rifting, J. Geol. Soc., 174, 522-540, https://doi.org/10.1144/jgs2016-050, 2017.

Phillips, T. B., Jackson, C. A.-L., Bell, R. E., and Duffy, O. B.: Oblique reactivation of lithosphere-scale lineaments controls rift physiography - the upper-crustal expression of the SorgenfreiTornquist Zone, offshore southern Norway, Solid Earth, 9, 403429, https://doi.org/10.5194/se-9-403-2018, 2018.

Phillips, T. B., Fazlikhani, H., Gawthorpe, R. L., Fossen, H., Jackson, C. A., Bell, R. E., Faleide, J. I., and Rotevatn, A.: The Influence of Structural Inheritance and Multiphase Extension on Rift Development, the NorthernNorth Sea, Tectonics, 38, 4099-4126, https://doi.org/10.1029/2019TC005756, 2019.

Puga, E., Fanning, M., Díaz de Federico, A., Nieto, J. M., Beccaluva, L., Bianchini, G., and Díaz Puga, M. A.: Petrology, geochemistry and U-Pb geochronology of the 
Betic Ophiolites: Inferences for Pangaea break-up and birth of the westernmost Tethys Ocean, Lithos, 124, 255-272, https://doi.org/10.1016/j.lithos.2011.01.002, 2011.

Quintana, L., Pulgar, J. A., and Alonso, J. L.: Displacement transfer from borders to interior of a plate: A crustal transect of Iberia, Tectonophysics, 663, 378-398, https://doi.org/10.1016/j.tecto.2015.08.046, 2015

Quirk, D. G. and Rüpke, L. H.: Melt-induced buoyancy may explain the elevated rift-rapid sag paradox during breakup of continental plates, Sci. Rep.-UK, 8, 1-13, https://doi.org/10.1038/s41598018-27981-2, 2018.

Ramos, A., Fernández, O., Terrinha, P., and Muñoz, J. A.: Extension and inversion structures in the Tethys-Atlantic linkage zone, Algarve Basin, Portugal, Int. J. Earth Sci., 105, 1663-1679, https://doi.org/10.1007/s00531-015-1280-1, 2016.

Rasmussen, E. S., Lomholt, S., Andersen, C., and Vejbæk, O. V.: Aspects of the structural evolution of the Lusitanian Basin in Portugal and the shelf and slope area offshore Portugal, Tectonophysics, 300, 199-225, https://doi.org/10.1016/S00401951(98)00241-8, 1998.

Rat, J., Mouthereau, F., Brichau, S., Crémades, A., Bernet, M., Balvay, M., Ganne, J., Lahfid, A., and Gautheron, C.: Tectonothermal Evolution of the Cameros Basin: Implications for Tectonics of North Iberia, Tectonics, 38, 440-469, https://doi.org/10.1029/2018TC005294, 2019.

Salas, R. and Casas, A.: Mesozoic extensional tectonics, stratigraphy and crustal evolution during the Alpine cycle of the eastern Iberian basin, Tectonophysics, 228, 33-55, https://doi.org/10.1016/0040-1951(93)90213-4, 1993.

Salas, R., Guimerà, J., Mas, R., Martín-Closas, C., Melendez, A., and Alonso, A.: Evolution of the Mesozoic Central Iberian Rift System and its Cainozoic inversion (Iberian chain), in: PeriTethys Memoir 6: Peri-Tethyan Rift/Wrench Basins and Passive Margins, edited by: Ziegler, P. A., Cavazza, W., Robertson, A., and Crasquin-Soleau, S., Paris, Mémoir du Muséum d'Histoire Naturelle edn., 186, 145-186, 2001.

Sallarès, V., Martínez-Loriente, S., Prada, M., Gràcia, E., Ranero, C., Gutscher, M. A., Bartolome, R., Gailler, A., Dañobeitia, J. J., and Zitellini, N.: Seismic evidence of exhumed mantle rock basement at the Gorringe Bank and the adjacent Horseshoe and Tagus abyssal plains (SW Iberia), Earth Planet. Sci. Lett., 365, 120131, https://doi.org/10.1016/j.epsl.2013.01.021, 2013.

Sánchez-Navas, A., García-Casco, A., Mazzoli, S., and MartínAlgarra, A.: Polymetamorphism in the Alpujarride Complex, Betic Cordillera, South Spain, J. Geol., 125, 637-657, https://doi.org/10.1086/693862, 2017.

Sandoval, L., Welford, J. K., MacMahon, H., and Peace, A. L.: Determining continuous basins across conjugate margins: The East Orphan, Porcupine, and Galicia Interior basins of the southern North Atlantic Ocean, Mar. Petrol. Geol., 110, 138-161, https://doi.org/10.1016/j.marpetgeo.2019.06.047, 2019.

Saspiturry, N., Cochelin, B., Razin, P., Leleu, S., Lemirre, B., Bouscary, C., Issautier, B., Serrano, O., Lasseur, E., Baudin, T., and Allanic, C.: Tectono-sedimentary evolution of a rift system controlled by Permian post-orogenic extension and metamorphic core complex formation (Bidarray Basin and Ursuya dome, Western Pyrenees), Tectonophysics, 768, 228180, https://doi.org/10.1016/j.tecto.2019.228180, 2019.
Schaltegger, U., Desmurs, L., Manatschal, G., Müntener, O., Meier, M., Frank, M., and Bernoulli, D.: The transition from rifting to sea-floor spreading within a magma-poor rifted margin: Field and isotopic constraints, Terra Nova, 14, 156-162, 2002.

Schettino, A. and Turco, E.: Breakup of Pangaea and plate kinematics of the central Atlantic and Atlas regions, Geophys. J. Int., 178, 1078-1097, https://doi.org/10.1111/j.1365-246X.2009.04186.x, 2009.

Schettino, A. and Turco, E.: Tectonic history of the Western Tethys since the Late Triassic, B. Geol. Soc. Am., 123, 89-105, https://doi.org/10.1130/B30064.1, 2011.

Schmid, S. M., Bernoulli, D., Fügenschuh, B., Matenco, L., Schefer, S., Schuster, R., Tischler, M., and Ustaszewski, K.: The Alpine-Carpathian-Dinaridic orogenic system: Correlation and evolution of tectonic units, Swiss J. Geosci., 101, 139-183, https://doi.org/10.1007/s00015-008-1247-3, 2008.

Scisciani, V. and Esestime, P.: The Triassic evaporites in the evolution of the Adriatic Basin, in: Permo-Triassic Salt Provinces of Europe, North Africa and the Atlantic Margins, Elsevier, 499516, 2017.

Serrano, O., Delmas, J., Hanot, F., Vially, R., Herbin, J.-P., Houel, P., and Tourlière, B.: Le Bassin d'Aquitaine: valorisation des données sismiques, cartographie structurale et potentiel pétrolier, Tech. rep., BRGM \& IFP, Orléans, 2006.

Seton, M., Müller, R. D., Zahirovic, S., Gaina, C., Torsvik, T. H., Shephard, G. E., Talsma, A., Gurnis, M., Turner, M., Maus, S., and Chandler, M.: Global continental and ocean basin reconstructions since $200 \mathrm{Ma}$, Earth-Sci. Rev., 113, 212-270, https://doi.org/10.1016/j.earscirev.2012.03.002, 2012.

Sibuet, J. C., Srivastava, S. P., and Spakman, W.: Pyrenean orogeny and plate kinematics, J. Geophys. Res.-Sol. Ea., 109, 1-18, https://doi.org/10.1029/2003JB002514, 2004.

Silver, P. G., Behn, M. D., Kelley, K., Schmitz, M., and Savage, B.: Understanding cratonic flood basalts, Earth Planet. Sc. Lett., 245, 190-201, https://doi.org/10.1016/j.eps1.2006.01.050, 2006.

Simon, N. S. and Podladchikov, Y. Y.: The effect of mantle composition on density in the extending lithosphere, Earth Planet. Sc. Lett., 272, 148-157, https://doi.org/10.1016/j.eps1.2008.04.027, 2008.

Solé, J., Cosca, M., Sharp, Z., and Enrique, P.: ${ }^{40} \mathrm{Ar} /{ }^{39} \mathrm{Ar}$ Geochronology and stable isotope geochemistry of LateHercynian intrusions from north-eastern Iberia with implications for argon loss in K-feldspar, Int. J. Earth Sci., 91, 865-881, https://doi.org/10.1007/s00531-001-0251-x, 2002.

Sopeña, A., López, J., Arche, A., Pérez-Arlucea, M., Ramos, A., Virgili, C., and Hernando, S.: Permian and Triassic rift basins of the Iberian Peninsula, in: Developments in Geotectonics, 22, 757-786, https://doi.org/10.1016/B978-0-444-42903-2.50036-1, 1988.

Soto, R., Casas-Sainz, A. M., Oliva-Urcia, B., García-Lasanta, C., Izquierdo-Llavall, E., Moussaid, B., Kullberg, J. C., RománBerdiel, T., Sánchez-Moya, Y., Sopeña, A., Torres-López, S., Villalaín, J. J., El-Ouardi, H., Gil-Peña, I., and Hirt, A. M.: Triassic stretching directions in Iberia and North Africa inferred from magnetic fabrics, Terra Nova, 31, 465-478, https://doi.org/10.1111/ter.12416, 2019.

Spooner, C., Stephenson, R., and Butler, R. W.: Pooled subsidence records from numerous wells reveal variations in prebreak-up rifting along the proximal domains of the Iberia- 
Newfoundland continental margins, Geol. Mag., 156, 13231333, https://doi.org/10.1017/S0016756818000651, 2019.

Stampfli, G. M. and Borel, G. D.: A plate tectonic model for the Paleozoic and Mesozoic constrained by dynamic plate boundaries and restored synthetic oceanic isochrons, Earth Planet. Sc. Lett., 196, 17-33, https://doi.org/10.1016/S0012-821X(01)00588-X, 2002.

Stampfli, G. M., Mosar, J., Favre, P., Pillevuit, A., and Vannay, J.C.: Permo-Mesozoic evolution of the western Tethyan realm: the Neotethys/East- Mediterranean connection, in: Peri-Tethys Memoir 6: Peri-Tethyan Rift/Wrench Basins and Passive Margins, edited by: Ziegler, P. A., Cavazza, W., Robertson, A. H. F., and Crasquin-Soleau, S., Mémoirs du Muséum d'Histoire Naturelle, Paris, 186, 51-108, 2001.

Srivastava, S. P., Sibuet, J. C., Cande, S., Roest, W. R., and Reid, I. D.: Magnetic evidence for slow seafloor spreading during the formation of the Newfoundland and Iberian margins, Earth Planet. Sc. Lett., 182, 61-76, https://doi.org/10.1016/S0012821X(00)00231-4, 2000.

Štolfová, K. and Shannon, P. M.: Permo-Triassic development from Ireland to Norway: basin architecture and regional controls, Geol. J., 44, 652-676, 2009.

Tankard, A. J. and Welsink, H. J.: Extensional tectonics and stratigraphy of Hibernia oil field, Grand Banks, Newfoundland, AAPG Bulletin, 71, 1210-1232, 1987.

Tavani, S. and Granado, P.: Along-strike evolution of folding, stretching and breaching of supra-salt strata in the Plataforma Burgalesa extensional forced fold system (northern Spain), Basin Res., 27, 573-585, https://doi.org/10.1111/bre.12089, 2015.

Tavani, S., Quintà, A., and Granado, P.: Tectonophysics Cenozoic right-lateral wrench tectonics in the Western Pyrenees (Spain): The Ubierna Fault System, Tectonophysics, 509, 238253, https://doi.org/10.1016/j.tecto.2011.06.013, 2011.

Tavani, S., Bertok, C., Granado, P., Piana, F., Salas, R., Vigna, B., and Muñoz, J. A.: The Iberia-Eurasia plate boundary east of the Pyrenees, Earth-Sci. Revi., 187, 314-337, https://doi.org/10.1016/j.earscirev.2018.10.008, 2018.

Thinon, I., Fidalgo-González, L., Réhault, J. P., and Olivet, J. L.: Déformations pyrénéennes dans le golfe de Gascogne, Comptes Rendus de l'Academie de Sciences - Serie IIa: Sciences de la Terre et des Planetes, 332, 561-568, https://doi.org/10.1016/S1251-8050(01)01576-2, 2001.

Thinon, I., Réhault, J. P., and Fidalgo-González, L.: La couverture sédimentaire syn-rift de la marge Nord-Gascogne et du Bassin armoricain (golfe de Gascogne): à partir de nouvelles données de sismique réflexion, Bulletin de la Societe Geologique de France, 173, 515-522, https://doi.org/10.2113/173.6.515, 2002.

Tugend, J., Manatschal, G., Kusznir, N. J., Masini, E., Mohn, G., and Thinon, I.: Formation and deformation of hyperextended rift systems: Insights from rift domain mapping in the Bay of Biscay-Pyrenees, Tectonics, 33, 1239-1276, https://doi.org/10.1002/2014TC003529, 2014

Tugend, J., Manatschal, G., and Kusznir, N. J.: Spatial and temporal evolution of hyperextended rift systems: Implication for the nature, kinematics, and timing of the Iberian- European plate boundary, Geology, 43, 15-18, https://doi.org/10.1130/G36072.1, 2015.

Tugend, J., Chamot-Rooke, N., Arsenikos, S., Blanpied, C., and Frizon de Lamotte, D.: Geology of the Ionian Basin and Mar- gins: A Key to the East Mediterranean Geodynamics, Tectonics, 38, 2668-2702, https://doi.org/10.1029/2018TC005472, 2019.

Upton, B. G. J., Stephenson, D., Smedley, P. M., Wallis, S. M., and Fitton, J. G.: Carboniferous and Permian magmatism in Scotland, Geol. Soc. Spec. Publ., 223, 195-218, 2004.

Vacherat, A., Mouthereau, F., Pik, R., Huyghe, D., Paquette, J. L., Christophoul, F., Loget, N., and Tibari, B.: Rift-to-collision sediment routing in the Pyrenees: A synthesis from sedimentological, geochronological and kinematic constraints, Earth-Sci. Rev., 172, 43-74, https://doi.org/10.1016/j.earscirev.2017.07.004, 2017.

van Hinsbergen, D. J., Torsvik, T. H., Schmid, S. M., Maţenco, L. C., Maffione, M., Vissers, R. L., Gürer, D., and Spakman, W.: Orogenic architecture of the Mediterranean region and kinematic reconstruction of its tectonic evolution since the Triassic, Gondwana Research, 81, 79-229, https://doi.org/10.1016/j.gr.2019.07.009, 2020.

Van Wees, J. D., Arche, A., Beijdorff, C. G., López-Gómez, J., and Cloetingh, S. A.: Temporal and spatial variations in tectonic subsidence in the Iberian Basin (eastern Spain): Inferences from automated forward modelling of high-resolution stratigraphy (Permian-Mesozoic), Tectonophysics, 300, 285310, https://doi.org/10.1016/S0040-1951(98)00244-3, 1998.

Van Wees, J. D., Stephenson, R., Ziegler, P. A., Bayer, U., McCann, T., Dadlez, R., Gaupp, R., Narkiewicz, M., Bitzer, F., and Scheck, M.: On the origin of the southern Permian Basin, Central Europe, Mar. Petrol. Geol., 17, 43-59, 2000.

Vargas, H., Gaspar-Escribano, J. M., López-Gómez, J., Van Wees, J. D., Cloetingh, S., de La Horra, R., and Arche, A.: A comparison of the Iberian and Ebro Basins during the Permian and Triassic, eastern Spain: A quantitative subsidence modelling approach, Tectonophysics, 474, 160-183, https://doi.org/10.1016/j.tecto.2008.06.005, 2009.

Vergés, J., Poprawski, Y., Almar, Y., Drzewiecki, P. A., Moragas, M., Bover-Arnal, T., Macchiavelli, C., Wright, W., Messager, G., Embry, J., and Hunt, D.: Tectonosedimentary evolution of Jurassic-Cretaceous diapiric structures: Miravete anticline, Maestrat Basin, Spain, Basin Res., https://doi.org/10.1111/bre.12447, online first, 2020.

Vielzeuf, D. and Kornprobst, J.: Crustal splitting and the emplacement of Pyrenean lherzolites and granulites - A reply to M. W. Fischer, Earth Planet. Sc. Lett., 70, 439-443, https://doi.org/10.1016/0012-821X(84)90028-1, 1984.

Vissers, R.: Variscan extension in the Pyrenees, Tectonics, 11, 1369-1384, 1992.

Vissers, R. and Meijer, P.: Mesozoic rotation of Iberia: Subduction in the Pyrenees?, Earth-Sci. Rev., 110, 93-110, https://doi.org/10.1016/j.earscirev.2011.11.001, 2012.

Watts, A. B.: Isostasy and Flexure of the Lithosphere, Cambridge University Press, 2001.

Welsink, H. J., Dwyer, J. D., and Knight, R. J.: Tectono-Stratigraphy of the Passive Margin Off Nova Scotia, chap. 14, North American Margins, 1989.

Whitmarsh, R. B. and Manatschal, G.: Evolution of magma poor continental margins: from rifting to the onset of seafloor spreading, in: Regional Geology and Tectonics: Phanerozoic Passive Margins, Cratonic Basins and Global Tectonic Maps, edited by: Roberts, D. and Bally, A. W., chap. 9, Elsevier, 326-341, https://doi.org/10.1016/B978-0-444-56357-6.00008-1, 2012. 
Ziegler, P. A.: Geodynamic model for Alpine intra-plate compressional deformation in Western and Central Europe, in: Inversion Tectonics, edited by: Cooper, M. A. and Williams, G. D., Geol. Soc. Spec. Publ., 3, 63-85, 1989.

Ziegler, P. A.: Collision related intra-plate compression deformations in Western and Central Europe, J. Geodyn., 11, 357-388, 1990.

Ziegler, P. A. and Dèzes, P.: Crustal evolution of Western and Central Europe, Geol. Soc. Mem., 32, 43-56, https://doi.org/10.1144/GSL.MEM.2006.032.01.03, 2006.
Ziegler, P. A., Schumacher, M. E., Dèzes, P., van Wees, J. D., and Cloetingh, S. A.: Post-Variscan evolution of the lithosphere in the Rhine Graben area: Constraints from subsidence modelling, Geol. Soc. Spec. Publ., 223, 289-317, https://doi.org/10.1144/GSL.SP.2004.223.01.13, 2004. 